\title{
Aerosol source apportionment from 1-year measurements at the CESAR tower in Cabauw, the Netherlands
}

\author{
Patrick Schlag $^{1,2}$, Astrid Kiendler-Scharr ${ }^{2}$, Marcus Johannes Blom ${ }^{3}$, Francesco Canonaco ${ }^{4}$, Jeroen \\ Sebastiaan Henzing ${ }^{5}$, Marcel Moerman ${ }^{5}$, André Stephan Henry Prévôt ${ }^{4}$, and Rupert Holzinger ${ }^{1}$ \\ ${ }^{1}$ Institute for Marine and Atmospheric Research Utrecht (IMAU), Utrecht University, Utrecht, the Netherlands \\ ${ }^{2}$ Institute for Energy and Climate Research (IEK-8): Troposphere, Forschungszentrum Jülich, Jülich, Germany \\ ${ }^{3}$ Energy Research Centre of the Netherlands (ECN), Petten, the Netherlands \\ ${ }^{4}$ Laboratory of Atmospheric Chemistry, Paul Scherrer Institute (PSI), Villigen, Switzerland \\ ${ }^{5}$ Netherlands Organisation for Applied Scientific Research (TNO), Utrecht, the Netherlands
}

Correspondence to: Patrick Schlag (p.schlag@fz-juelich.de)

Received: 10 November 2015 - Published in Atmos. Chem. Phys. Discuss.: 15 December 2015

Revised: 17 June 2016 - Accepted: 28 June 2016 - Published: 19 July 2016

\begin{abstract}
Intensive measurements of submicron aerosol particles and their chemical composition were performed with an Aerosol Chemical Speciation Monitor (ACSM) at the Cabauw Experimental Site for Atmospheric Research (CESAR) in Cabauw, the Netherlands, sampling at $5 \mathrm{~m}$ height above ground. The campaign lasted nearly 1 year from July 2012 to June 2013 as part of the EU-FP7ACTRIS project (Q-ACSM Network). Including equivalent black carbon an average particulate mass concentration of $9.50 \mu \mathrm{g} \mathrm{m}^{-3}$ was obtained during the whole campaign with dominant contributions from ammonium nitrate (45\%), organic aerosol (OA, 29\%), and ammonium sulfate (19\%). There were 12 exceedances of the World Health Organization (WHO) $\mathrm{PM}_{2.5}$ daily mean limit $\left(25 \mu \mathrm{g} \mathrm{m}^{-3}\right)$ observed at this rural site using $\mathrm{PM}_{1}$ instrumentation only. Ammonium nitrate and OA represented the largest contributors to total particulate matter during periods of exceedance.

Source apportionment of OA was performed season-wise by positive matrix factorization (PMF) using the multilinear engine 2 (ME-2) controlled via the source finder (SoFi). Primary organic aerosols were attributed mainly to traffic (8-16\% contribution to total OA, averaged season-wise) and biomass burning (0-23\%). Secondary organic aerosols (SOAs, 61-84\%) dominated the organic fraction during the whole campaign, particularly on days with high mass loadings. A SOA factor which is attributed to humic-like substances (HULIS) was identified as a highly oxidized background aerosol in Cabauw. This shows the importance of at-
\end{abstract}

mospheric aging processes for aerosol concentration at this rural site. Due to the large secondary fraction, the reduction of particulate mass at this rural site is challenging on a local scale.

\section{Introduction}

Atmospheric aerosols have large impacts on the climate directly by scattering and absorbing shortwave radiation. Besides the resulting influence on the visibility (Ramanathan et al., 2007; Romanou et al., 2007), this can have a cooling or heating effect on the atmosphere (IPCC, 2013). The indirect effect refers to the impact of particles on cloud formation and their properties.

In addition, particles can adversely impact human health by, e.g., increasing the probability of cardiopulmonary and lung cancer mortality (Pope et al., 2002). The World Health Organization (WHO) recently estimated that, globally, 3.7 million deaths were attributable to ambient air pollution in both cities and rural areas in 2012 (EU, 2008). This mortality is reported to be due to exposure to small particulate matter $\left(\mathrm{PM}_{10}\right)$, which can cause cardiovascular and respiratory disease and cancers. Particles with smaller diameters such as $\mathrm{PM}_{2.5}$ or $\mathrm{PM}_{1}$ are reported to have enhanced toxicological effects since they can deposit more deeply in the respiratory system and remain suspended for longer periods of time (Pope and Dockery, 2006). Therefore, a num- 
ber of institutions established several air quality standards for different particle sizes to limit aerosol mass. The WHO air quality guideline (global update 2005, WHO, 2006) defines a $\mathrm{PM}_{2.5}$ daily mean limit of $25 \mu \mathrm{g} \mathrm{m}^{-3}$ and a $\mathrm{PM}_{2.5}$ annual mean limit of $10 \mu \mathrm{g} \mathrm{m}^{-3}$. The European Union Air Quality Directive 2008/50/EC provides only a target value of the annual mean limit of $\mathrm{PM}_{2.5}$ of $25 \mu \mathrm{g} \mathrm{m}^{-3}$ (EU, 2008).

Air quality and climate effects are not only dependent on the particle number concentration and size but also on their chemical composition. This information is not only relevant to investigate the nature and magnitude of each effect but also for the identification and quantification of aerosol sources and mitigation strategies for a potential reduction of aerosol mass concentrations. Major inorganic components of $\mathrm{PM}_{1}$ consist mainly of ammonium nitrate $\left(\mathrm{NH}_{4} \mathrm{NO}_{3}\right)$ and ammonium sulfate $\left(\left(\mathrm{NH}_{4}\right)_{2} \mathrm{SO}_{4}\right)$, formed in the presence of ammonia $\left(\mathrm{NH}_{3}\right)$, nitrogen oxides $\left(\mathrm{NO}_{x}\right.$ is $\mathrm{NO}$ plus $\left.\mathrm{NO}_{2}\right)$, and sulfur dioxide $\left(\mathrm{SO}_{2}\right)$, respectively (Seinfeld and Pandis, 2006). Therefore, $\mathrm{NH}_{4} \mathrm{NO}_{3}$ and $\left(\mathrm{NH}_{4}\right)_{2} \mathrm{SO}_{4}$ are strongly attributed to anthropogenic sources (Finlayson-Pitts and Pitts, 2000). Since inorganic aerosols are formed by gaseous precursors in the atmosphere, the condensed products are considered as secondary aerosols, while primary aerosols like black carbon (BC) are emitted directly.

In contrast, organic aerosols (OAs), which can also be of primary (POA) or secondary (SOA) origin, consist of up to hundreds of thousands of different molecules (Goldstein and Galbally, 2007), where SOA contributes on average $70 \%$ to organic aerosol mass (Hallquist et al., 2009). SOA is formed by gas-to-particle conversion of atmospherically oxidized semi- and low-volatile organic compounds (VOCs). Guenther et al. (1995) estimated a global VOC budget in the order of $1150 \mathrm{Tg}$ carbon per year. Biogenic VOCs (BVOCs) contribute approximately $90 \%$ of total $\mathrm{VOC}$, including isoprene (50\% of total BVOCs), monoterpenes ( $15 \%$ ), and sesquiterpenes (3\%) (Guenther et al., 2012). In turn, $10 \%$ of emitted VOCs are of anthropogenic origin, including, e.g., alkanes, alkenes, benzene, and toluene.

The investigation of the aerosol composition is critical for the development of climate models, since the composition influences important particle properties. However, its determination is still challenging, especially in case of OAs, which contribute significantly to atmospheric particulate matter (Jimenez et al., 2009). In fact, the lack of knowledge on particle composition is a key contribution to the large uncertainty for the determination of the total anthropogenic radiative forcing (IPCC, 2013).

The development of online aerosol mass spectrometric techniques during the last decades enhanced the possibilities to investigate aerosol chemical composition in real time (DeCarlo et al., 2006; Jayne et al., 2000; Jimenez et al., 2003). The Aerosol Mass Spectrometer (AMS, Aerodyne Research Inc., Billerica, MA, USA) is a powerful instrument to quantitatively measure the chemical composition of the nonrefractory fraction of $\mathrm{PM}_{1}\left(\mathrm{NR}-\mathrm{PM}_{1}\right)$ with high time and mass res- olution. Due to the high amount of maintenance from skilled and trained personnel needed for continuous operating measurement, campaigns using an AMS usually do not exceed 1 or 2 months (Sun et al., 2012). Since the variation of aerosol composition is very high depending on measurement site and season (Jimenez et al., 2009), long-term measurements ( $\geq 1$ year) are clearly needed. At a European level, this effort is supported by the Aerosols, Clouds and Traces gases Research InfraStructure network (ACTRIS) program that aims at pooling high-quality data from state-of-the-art instrumentation, such as the Aerodyne Aerosol Chemical Speciation Monitor (ACSM). The quadrupole ACSM (Q-ACSM) is specially designed for long-term continuous and real-time measurements of mass concentrations and composition of NR$\mathrm{PM}_{1}$ species (Ng et al., 2011b).

In this study, an ACSM was used to measure the submicron aerosol chemical composition from 11 July 2012 to 3 June 2013 at the CESAR tower in Cabauw, the Netherlands, as part of the EU-FP7-ACTRIS project. A collocated multi-angle absorption photometer (MAAP, Thermo Scientific Model 5012) provided equivalent black carbon (eBC) data. Organic aerosol data were further analyzed by positive matrix factorization using the multilinear engine 2 (ME-2) (Paatero, 1999) via the source finder (SoFi, Canonaco et al., 2013). This data set shows the long-term variability of particle composition and is used for source apportionment of atmospheric aerosols at this northwestern European rural site, with the focus on periods where air quality standards were violated. Information about aerosol composition and their sources especially during pollution events can be further used to establish strategies for the reduction of particulate matter.

\section{Methodology}

\subsection{Site description: CESAR}

The CESAR tower is $220 \mathrm{~m}$ high and managed and operated by the Royal Netherlands Meteorological Institute (KNMI, the Netherlands). It is located in a rural site $\left(51.970^{\circ} \mathrm{N}\right.$, $4.926^{\circ} \mathrm{E}$ ) near Cabauw, the Netherlands, about $20 \mathrm{~km}$ southwest of the city of Utrecht and about $45 \mathrm{~km}$ southeast of the Dutch North Sea coast. The site conditions are typical for northwestern Europe. They can either be maritime or continental, depending on the wind direction. The surface elevation changes in the surrounding area are, at most, a few meters over $20 \mathrm{~km}$. The tower ground is approximately $0.7 \mathrm{~m}$ below sea level; the diurnal variation of the temperature is relatively stable (Vermeulen et al., 2011). The direct surroundings of the tower have a relatively low population density. The nearby region is used mainly by agriculture, with a mixture of intensively and extensively managed grassland. These are used also for keeping animals like cattle and sheep beside nearby chicken farms. 
The tower is equipped with external platforms and booms at 2, 10, 20, 40, 80, 140, and $200 \mathrm{~m}$. At all these levels, meteorological observations of standard parameters like wind speed, wind direction, dew point temperature, and ambient temperature are routinely performed (Ulden and Wieringa, 1996). These data sets are available at the CESAR database (KNMI, 2013). In addition, other meteorological data like precipitation, radiation, and remote sensing, including lidar, radar, and radiometer techniques, are acquired at the tower and submitted to the CESAR database. Also concentrations of gaseous compounds, including greenhouse gases, are monitored at CESAR (Russchenberg et al., 2005; Vermeulen et al., 2011). The National Institute for Public Health and the Environment (RIVM, the Netherlands) provides hourly data from gaseous $\mathrm{CO}, \mathrm{NO}, \mathrm{NO}_{2}, \mathrm{SO}, \mathrm{SO}_{2}$, and $\mathrm{O}_{3}$, but also daily $\mathrm{PM}_{10}$ measurements. Data of ambient $\mathrm{CO}_{2}, \mathrm{CH}_{4}$ (both measured at 20,60, 120, and $200 \mathrm{~m}$ height), and radon 222 $\left({ }^{222} \mathrm{Rn}\right.$, measured at 20 and $200 \mathrm{~m}$ height) are determined by ECN on a timescale of $30 \mathrm{~min}$. A map indicating the land use of the Netherlands is given in the Supplement (Fig. S1).

\subsection{ACSM sampling and data analysis}

The ACSM measures the NR-PM $\mathrm{P}_{1}$ fraction, including the organic fraction (Org), ammonium $\left(\mathrm{NH}_{4}\right)$, nitrate $\left(\mathrm{NO}_{3}\right)$, sulfate $\left(\mathrm{SO}_{4}\right)$, and chloride $(\mathrm{Chl})$, using mass spectrometric information on a timescale of approximately $30 \mathrm{~min}$. The ACSM used in this work is equipped with a commercial grade quadrupole residual gas analyzer (RGA); thus, it is also called a Q-ACSM. This instrument is described in detail by $\mathrm{Ng}$ et al. (2011b). The RGA provides unit mass resolution (UMR) mass spectra. Fractions of measured UMR signals were assigned to individual aerosol species using the fragmentation table introduced by Allan et al. (2004). Due to the automated zeroing system used for the ACSM, adjustments of the fragmentation table entries concerning interferences from air beam molecules are not needed. All ACSM data processing and analysis within this work was performed using software provided by Aerodyne Research (ACSM Local, version 1.531, ARI, 2012) within IGOR Pro version 6.2.3.

Recent studies showed good agreements of ACSM data with data from other aerosol instruments like the highresolution time-of-flight AMS (HR-ToF-AMS) in ambient measurement campaigns, even in highly polluted areas such as Beijing (Sun et al., 2012, 2011). An intercomparison of two collocated ACSMs resulted in strong correlations $\left(R^{2}=0.8\right)$ and agreements within $27 \%$ (Budisulistiorini et al., 2014). Crenn et al. (2015) reported similar results from the intercomparison of 13 ACSMs, a ToF-ACSM, a ToFAMS, and other collocated instruments in the region of Paris, France. There, the same ACSM instrument (S/N A140-145) as the one used for this study was tested. Those results indicate that the ACSM can be used as a suitable and costeffective alternative to the AMS for aerosol composition measurements due to its capability of stable and reproducible operation.

Mass calibrations were performed approximately every month and were based on determining the instrument response factor (RF) ( $\mathrm{Ng}$ et al., 2011b) using monodisperse $\mathrm{NH}_{4} \mathrm{NO}_{3}(320 \mathrm{~nm})$ as calibration substance and a condensation particle counter (CPC, TSI 3022a) as reference instrument (Jayne et al., 2000; Jimenez et al., 2003). An average $\mathrm{RF}_{\mathrm{NO}_{3}}$ of $2.74 \pm 0.45 \times 10^{-11}$ was obtained and used for the calculation of aerosol mass concentrations. Instead of performing a mass calibration for every aerosol species, relative ionization efficiencies (RIEs), compared to those of nitrate, were used. The RIEs of $\mathrm{NH}_{4}$ and $\mathrm{SO}_{4}$ were determined directly during the mass calibrations by measuring dry $\mathrm{NH}_{4} \mathrm{NO}_{3}$ and $\left(\mathrm{NH}_{4}\right)_{2} \mathrm{SO}_{4}$ particles after another. Averaged over all calibrations, a $\mathrm{RIE}_{\mathrm{NH}_{4}}$ of $7.53 \pm 0.21$ and a $\mathrm{RIE}_{\mathrm{SO}_{4}}$ of $0.81 \pm 0.10$ were found and used for the whole data set. Calibration results gained from this particular instrument during an intercomparison in Paris as described by Crenn et al. (2015) were within the uncertainty or only slightly different $\left(\mathrm{RF}_{\mathrm{NO}_{3}}=2.34 \times 10^{-11}, \mathrm{RIE}_{\mathrm{NH}_{4}}=6.54, \mathrm{RIE}_{\mathrm{SO}_{4}}=0.62\right)$ considering the large differences between individual instruments at the intercomparison. RIE values of 1.4 and 1.3 for organics and chloride, respectively, were taken from the literature (Alfarra et al., 2004; Canagaratna et al., 2007).

A site-specific, time-resolved particle collection efficiency (CE) correction algorithm (equations are given in the Supplement) was applied, which was developed by Mensah et al. (2012), using SMPS data as reference. In contrast to the commonly used constant value of 0.5 , this CE correction accounts for the high ammonium nitrate mass fraction (ANMF) found at this site and is thus more suitable for the data presented here. Another algorithm for composition-dependent CE determination (Middlebrook et al., 2012) was also tested for its validity. It uses a threshold ratio of measured-topredicted $\mathrm{NH}_{4}$ to switch between two different equations to determine the $\mathrm{CE}$. The threshold value of 0.75 is close to the observed ratio of measured-to-predicted $\mathrm{NH}_{4}$ of this data set, resulting in large discontinuities of $\mathrm{CE}$ values and in consequence, discontinuous changes in aerosol mass concentrations. Therefore, the Middlebrook algorithm was not used for this data set, which showed, at the same time, low ratios of measured-to-predicted $\mathrm{NH}_{4}$ and high ANMFs. According to $\mathrm{Ng}$ et al. (2011b) and Sun et al. (2012), the variability of the instrument performance was corrected based on the inlet pressure and $\mathrm{N}_{2}$ signal, as well as the signals derived from the internal naphthalene source were taken to correct for the mass-dependent ion transmission efficiency of the RGA.

The detection limits for each species were not determined within this work but are reported to be $0.148,0.284,0.012$, 0.024 , and $0.011 \mu \mathrm{g} \mathrm{m}^{-3}(3 \sigma)$ for organics, ammonium, nitrate, sulfate, and chloride, respectively, at an averaging time of $30 \mathrm{~min}$ ( $\mathrm{Ng}$ et al., 2011b).

During the whole campaign, the ACSM was located inside the CESAR tower building. Its inlet was placed on the roof 
of the building at approximately $5 \mathrm{~m}$ height above ground. The inlet head was equipped with a $\mathrm{PM}_{2.5}$ cyclone (URG2000-30EN, URG Corporation, Chapel Hill, USA). The sample air was pulled through a $10 \mathrm{~m}$ copper line (ID $=6.5 \mathrm{~mm}$ ) at a flow rate of $9 \mathrm{~L} \mathrm{~min}^{-1}$. From this flow, a subsample of $1 \mathrm{~L} \mathrm{~min}^{-1}$ was diverted to a Nafion dryer $(\mathrm{RH}<40 \%)$ of which approximately $80 \mathrm{~mL} \mathrm{~min}^{-1}$ entered the ACSM. This resulted in a total residence time of $18 \mathrm{~s}$.

\subsection{Collocated aerosol measurements}

The following collocated aerosol instruments were used for cross validation of the ACSM data: (i) a scanning mobility particle sizer (SMPS, TSI 3034), operated by the Netherlands Organization for Applied Scientific Research (TNO, the Netherlands); (ii) a monitor for aerosol and gases (MARGA, Applikon Analytical BV), operated by ECN; and (iii) a HRToF-AMS, which was operated by Forschungszentrum Jülich during the first 6 days of the ACSM campaign. In addition, BC data obtained by a MAAP instrument (TNO, the Netherlands) were included into the analysis.

The MAAP instrument has been introduced by Petzold and Schönlinner (2004) and Petzold et al. (2005). It is designed for the determination of the black carbon (BC), which is a product of incomplete combustion. There is a general consensus in the scientific community about the properties of black carbon (Bond et al., 2013). The MAAP measures the strong visible light absorption property of $\mathrm{BC}$ by simultaneous measurements of the radiation penetrating through and scattered back from a particle-loaded fiber filter. According to Petzold et al. (2013), optical BC determined by MAAP is to be referred to as equivalent black carbon (eBC). One property of $\mathrm{BC}$ is that it is highly refractory with a vaporization temperature near $4000 \mathrm{~K}$ (Schwarz et al., 2006); thus, $\mathrm{BC}$ is not vaporized at $600^{\circ} \mathrm{C}$ and cannot be measured by the ACSM. The MAAP achieves a time resolution of $5 \mathrm{~min}$ with an uncertainty of $12 \%$ (Petzold and Schönlinner, 2004). A mass absorption cross section (MAC) of $6.6 \mathrm{~m}^{2} \mathrm{~g}^{-1}$ for a wavelength of $637 \mathrm{~nm}$ (Müller et al., 2011) was chosen to convert the measured particle absorption coefficient to $\mathrm{eBC}$ mass concentrations. Although the MAAP has no sizeselective inlet beside the $\mathrm{PM}_{10}$ heads described below, it can be assumed that $\mathrm{eBC}$-containing aerosols generally fall into the submicron size range (Bond et al., 2013). Thus, eBC mass concentrations are considered as part of the $\mathrm{PM}_{1}$ fraction from here on. As seen later, the eBC fraction is rather low throughout the campaign, meaning that the overall error of this assumption is not significant.

The SMPS (TSI, Model 3034) is a sequential combination of several integrated components: an impactor, a neutralizer, a differential mobility analyzer, and a condensation particle counter. It determines the size distribution of particles in a range of $10-487 \mathrm{~nm}$ (electromobility diameter). The SMPS aerosol mass concentration was calculated from the measured volume distributions using the particle density deter- mined by the aerosol composition information derived from the ACSM and the MAAP. Assuming spherical particles, the total density is computed by using the densities of the aerosol species, weighted by their mass fractions. Bulk densities of $\mathrm{NH}_{4} \mathrm{NO}_{3}\left(1.72 \mathrm{~g} \mathrm{~cm}^{-3}\right)$ and $\left(\mathrm{NH}_{4}\right)_{2} \mathrm{SO}_{4}\left(1.77 \mathrm{~g} \mathrm{~cm}^{-3}\right)$, and densities of $1.8 \mathrm{~g} \mathrm{~cm}^{-3}$ for BC (Bond and Bergstrom, 2006; Park et al., 2004) of organics $\left(1.4 \mathrm{~g} \mathrm{~cm}^{-3}\right.$, Hallquist et al., 2009) were taken into account. Considering its low influence on the total particle density at this site, it is acceptable to set the density for chloride to $1 \mathrm{~g} \mathrm{~cm}^{-3}$ (Mensah et al., 2012).

During the presented campaign, the MAAP and the SMPS were connected to the common aerosol inlet which sampled at $60 \mathrm{~m}$ height. This inlet consisted of four $\mathrm{PM}_{10}$ sizeselective heads at the top, followed by a Nafion dryer to keep the relative humidity (RH) of the sample air below $40 \%$. The stainless steel pipe, ranging from the aperture at $60 \mathrm{~m}$ to the basement, has an inner diameter of $0.5^{\prime \prime}(1.27 \mathrm{~cm})$ and ends in a manifold, where the sampled air is distributed to a variety of different instruments, including the MAAP and the SMPS, each with its own sample flow. An overall sample flow of $60 \mathrm{~L} \mathrm{~min}^{-1}$ was adjusted inside the $60 \mathrm{~m}$ pipe, assuring laminar conditions.

SMPS data were corrected size dependently for (diffusional) losses in the inlet system and SMPS system itself according to Henzing (2011), who compared theoretical findings with measured losses that are obtained by measuring simultaneously before and after the various parts of the inlet system at the CESAR tower. In addition, particles of different compositions were measured in 2013 simultaneously at the pipe entrance at $60 \mathrm{~m}$ height and in the basement (J. S. Henzing, personal communication, 2014). For more than 8000 simultaneous observations, the results showed that aerosol measurements through this $60 \mathrm{~m}$ sampling line underestimate $\mathrm{PM}_{10}$ eBC by approximately $33 \%$ with an uncertainty of $7 \%$. Therefore, eBC obtained from the MAAP are divided by a factor of 0.66 to account for these losses. For the inorganic species, penetrations through this inlet line were reported to be $62-73 \%$ for nitrate, $55-64 \%$ for sulfate, and $54-56 \%$ for ammonium. However, these results were not used for corrections in this work.

The MARGA measures water-soluble components of both the gas and aerosol phase simultaneously, including the aerosol species nitrate, ammonium, sulfate, and chloride. It uses a wet annular denuder (WAD) followed by a steam jet aerosol collector (SJAC). The operational and calibration procedures, as well as details of the data analysis are given by Trebs et al. (2004). During the campaign the MARGA collected alternately the $\mathrm{PM}_{1}$ and $\mathrm{PM}_{2.5}$ fraction of ambient particles at ambient RH and temperature, each fraction sampled hourly with a measurement error smaller than $10 \%$ (Schaap et al., 2011). The detection limits for the most abundant aerosol species were $0.05,0.10,0.08$, and $0.01 \mu \mathrm{g} \mathrm{m}^{-3}$ ( $4 \sigma$, Rumsey et al., 2014) for ammonium, nitrate, sulfate, and chloride, respectively. 
The MARGA inlet was equipped with a $\mathrm{PM}_{10}$ sizeselective head (Rupprecht and Pataschnick, R\&P), placed on the roof of the tower building next to the ACSM inlet aperture at $5 \mathrm{~m}$ height. The sample air was transferred into the instrument within a polyethylene tube with an inner diameter of $0.5^{\prime \prime}(1.27 \mathrm{~cm})$ and a sample flow of $16.7 \mathrm{~L} \mathrm{~min}^{-1}$, which is either directed through a $\mathrm{PM}_{1}$ or a $\mathrm{PM}_{2.5}$ sizeselective cyclone. A detailed description of the MARGA inlet system at the Cabauw tower was previously described by Schaap et al. (2011). There, wall losses were investigated and found to be less than $2 \%$ for several gaseous and particulate compounds. To compare with the ACSM, only MARGA data containing $\mathrm{PM}_{1}$ composition are considered within this work.

An Aerodyne HR-ToF-AMS was connected to the MARGA inlet during the first 6 days of the campaign. As the ACSM is built upon AMS, the latter likewise measures the chemical composition of the $\mathrm{PM}_{1}$ nonrefractory (NR) fraction. Instrumental details are available in Jayne et al. (2000), Jimenez et al. (2003), and DeCarlo et al. (2006).

\subsection{Statistical methods of organic aerosol data analysis}

Source apportionment of organic aerosol components was performed using positive matrix factorization (PMF, Paatero, 1997; Paatero and Tapper, 1994) via the ME-2 solver (Paatero, 1999). PMF is a bilinear model and assumes that the original data set, containing variable mass spectra over time, is a linear combination of a given number of factors, each with a constant mass spectrum and varying contribution over time. It has been successfully used in AMS ambient studies apportioning the measured organic mass spectra in terms of source- and process-related components (Zhang et al., 2011). With the ME-2 solver it is possible to introduce a priori mass spectral information and hence to reduce the rotational ambiguity, i.e., similar PMF results with the same goodness of fit, of PMF solutions (Paatero and Hopke, 2003).

The extraction of OA data and error matrices as mass concentrations in $\mu \mathrm{g} \mathrm{m}^{-3}$ over time, as well as their preparation for PMF/ME-2 according to Ulbrich et al. (2009), was done within the ACSM software. Only $m / z s \leq 100$ were considered here since they represented nearly the whole OA mass (around $98 \%$ ) and did not interfere with ion fragments originating from naphthalene (e.g., $m / z 127,128$, and 129 , see also Sect. 2.2). From these matrices, the $m / z 12$ was discarded because it showed negative signals, probably due to a too-short delay time of the quadrupole scan (125 ms) after a valve switch (Fröhlich et al., 2015). In addition, the $m / z 37$ and $m / z 38$ were also removed from the organic matrices of the whole campaign except for winter 2013. This was done because the signal at these masses showed high interferences with the chloride-related ions ${ }^{37} \mathrm{Cl}$ and $\mathrm{H}^{37} \mathrm{Cl}$. Including these ions led to unreasonable PMF factors which mainly contained only these two masses and represented the chloride time series, whereas during winter 2013 no such interferences were observed.

The interface source finder (SoFi, Canonaco et al., 2013) version 4.8 was used to control ME-2 for the PMF runs of the ACSM OA data adopting the source apportionment strategy developed by Crippa et al. (2014). Briefly, unconstrained PMF runs were first investigated with 1-10 factors and a moderate number of seeds (10-15) for each factor number. If primary organic aerosol (POA) factor profiles such as hydrocarbon-like OA (HOA) or OA from biomass burning (BBOA) were found, site-specific POA mass spectra or spectra derived from the database were constrained and a sensitivity analysis performed on the tightness of constraint ( $a$ value, Lanz et al., 2008). Since aged OA (or oxidized OA, OOA) factors show more variability between measurement sites in terms of their mass spectra (MS) than POA, it is not appropriate to constrain SOA factor profiles using reference spectra derived from different locations (Canonaco et al., 2015). According to Crippa et al. (2014), HOA MS should be more constrained ( $a$ value between 0 and 0.2) than BBOA MS ( $a \approx 0.3$ ), since the BBOA fingerprint shows higher variations depending on the burning type and conditions (Alfarra et al., 2007). In each step, either in unconstrained or constrained approaches, the following criteria for finding a proper solution were used based on the recommendations from Ulbrich et al. (2009) and Canonaco et al. (2013):

- The quality parameter $Q / Q_{\exp }$ was minimized.

- Factor profiles have reasonable MS, as expected for the measurement site.

- Factor time series have high correlations with respective external data sets such as gaseous $\mathrm{CO}, \mathrm{CO}_{2}, \mathrm{NO}_{x}$, and particulate nitrate, sulfate, and black carbon.

- When a proper solution is found, 50 seed runs were used to find the global minimum for $Q / Q_{\text {exp }}$.

- Investigation of the rotational ambiguity of the solution space is carried out using the $a$ value approach for the constrained factor profiles.

\section{Results and discussion}

\subsection{Cross validation of particulate total mass and chemical species concentrations}

The particle density during the ACSM campaign was determined using the chemical composition data from the ACSM and the MAAP and resulted in an average of $1.63 \pm 0.12 \mathrm{~g} \mathrm{~cm}^{-3}$. The time series of the particle density is given in the Supplement. It was used to calculate the SMPS total mass concentration from its measured volume concentration throughout the campaign. Due to the relatively low 
signal-to-noise ratio of the ACSM, the density shows scattering only during periods with low mass loadings. Therefore, it does not influence the cross validation with the SMPS mass significantly. Figures S3 and S4 show the time series of the SMPS mass and the combined mass concentrations measured by ACSM and MAAP and the correlation plot of both data sets, respectively. Using 12275 common data points for the linear fit, a good qualitative and quantitative agreement (slope: $1.16 \pm 0.01$, intercept: $-1.05 \pm 0.06$, $R^{2}=0.78$ ) was observed. Excluding eBC data resulted in a slope of $1.13 \pm 0.01$, an intercept of $-1.14 \pm 0.06$, and an $R^{2}$ of 0.78 . The negative offset can be explained by minor influences of sea salt and dust particles, which can be detected well by the SMPS and MARGA but not by the ACSM with a sufficient sensitivity. But the low value of the intercept shows already that the uncertainty introduced by these aerosol components is rather low in general. This can also be explained by the low concentrations of $\mathrm{Mg}, \mathrm{Na}, \mathrm{K}$, and $\mathrm{Ca}$ as measured by the MARGA (see below) and the assumption that the majority of dust particles is most likely found in particles with diameters larger than 1 or even $2.5 \mu \mathrm{m}$ (Finlayson-Pitts and Pitts, 2000, and references therein).

Since the MARGA routinely measures the water-soluble inorganic aerosol compounds, data from ACSM inorganic species were synchronized and compared to corresponding MARGA $\mathrm{PM}_{1}$ data for the whole measurement period. The temporal overlap with the collocated high-resolution AMS was between 11 and 17 July 2012. The correlation parameters of individual aerosol species and respective total masses between the ACSM data and the data sets from the MARGA and AMS are given in Table 1, using 1943 and 294 common data points, respectively. The corresponding correlation graphs are shown in the Supplement (Figs. S5 and S6). Except for chloride, high correlation coefficients were achieved. Furthermore, the comparison to both total mass time evolutions shows very high qualitative and quantitative agreement. The quantitative difference between ACSM and AMS organics is also very low, and the discrepancies in case of ammonium and nitrate are within the stated $\pm 30 \%$ accuracy of the AMS and ACSM (Ng et al., 2011b) and the $\pm 10 \%$ for the MARGA $\mathrm{NO}_{3}$, respectively (Makkonen et al., 2012). Similar variations were also found by Crenn et al. (2015) as well as Budisulistiorini et al. (2014). The latter reported of a comparison between two collocated ACSMs $( \pm 27 \%$, $R^{2}=0.21$ for Chl, $R^{2}>0.8$ for the other species) and between these ACSMs and a continuous tapered element oscillating microbalance (TEOM, $\mathrm{PM}_{2.5}$ ) instrument. Note that the major ions used for nitrate detection in AMS and ACSM $\left(\mathrm{NO}^{+}\right.$and $\left.\mathrm{NO}_{2}^{+}\right)$are produced from both inorganic and organic nitrate (e.g., Farmer et al., 2010). The higher ACSM nitrate compared to MARGA nitrate can therefore also be explained by the presence of organic nitrates. In case of nitrate the ACSM and MARGA comparison cannot be seen as independent. The underestimation of the ACSM in case of sulfate exceeding the uncertainties may arise from calibra-
Table 1. Results of the ACSM to MARGA and ACSM to AMS comparisons for individual species and the respective total masses. Note that for comparison with the MARGA total mass concentrations only the ACSM inorganic species were considered.

\begin{tabular}{llrrr}
\hline & & Slope & Intercept $\left(\mu \mathrm{g} \mathrm{m}^{-3}\right)$ & $R^{2}$ \\
\hline $\mathrm{Chl}$ & MARGA & $0.49 \pm 0.02$ & $0.11 \pm 0.01$ & 0.24 \\
& AMS & $0.67 \pm 0.01$ & $-0.01 \pm 0.01$ & 0.31 \\
$\mathrm{NH}_{4}$ & MARGA & $0.88 \pm 0.01$ & $0.07 \pm 0.01$ & 0.93 \\
& AMS & $0.82 \pm 0.03$ & $0.01 \pm 0.02$ & 0.71 \\
$\mathrm{SO}_{4}$ & MARGA & $0.63 \pm 0.01$ & $-0.08 \pm 0.01$ & 0.86 \\
& AMS & $0.49 \pm 0.02$ & $-0.18 \pm 0.02$ & 0.76 \\
$\mathrm{NO}_{3}$ & MARGA & $1.23 \pm 0.01$ & $-0.37 \pm 0.03$ & 0.96 \\
& AMS & $1.17 \pm 0.02$ & $-0.04 \pm 0.02$ & 0.89 \\
Organics & AMS & $1.03 \pm 0.04$ & $0.07 \pm 0.04$ & 0.73 \\
\hline \multirow{2}{*}{ Total } & MARGA & $1.05 \pm 0.01$ & $-0.70 \pm 0.06$ & 0.93 \\
& AMS & $0.90 \pm 0.02$ & $-0.02 \pm 0.07$ & 0.84 \\
\hline
\end{tabular}

tion issues. The mass calibration procedure used in this work was mainly adopted from AMS procedures which may not be directly suitable for the ACSM. The RIE of sulfate might be overestimated due to high observed background signals during the calibration using $\left(\mathrm{NH}_{4}\right)_{2} \mathrm{SO}_{4}$ particles. An overestimated $\mathrm{RIE}_{\mathrm{SO}_{4}}$ results in underestimated mass concentrations. This would in turn explain the low $\mathrm{SO}_{4}$ mass concentrations comparing to the MARGA and AMS. Additionally, the ACSM fragmentation table could not be adjusted for interferences of ions from different aerosol species on the same $\mathrm{m} / \mathrm{z}$ properly because ACSM software used in this study did not allow plotting time series for specific fragments apportioned by the fragmentation table. Thus, the standard table had to be used. Furthermore, the MARGA measured only low concentrations of $\mathrm{Mg}, \mathrm{Na}, \mathrm{K}$, and $\mathrm{Ca}$ (average sum: $0.08 \mu \mathrm{g} \mathrm{m}^{-3}$ ). Thus, contributions of their corresponding sulfate salts, for which the ACSM is less sensitive, are negligible in this context. It should also be noted that chloride concentrations can originate from particulate organic and inorganic chloride components originating from, e.g., sea salt. For the latter, the ACSM is much less sensitive than the MARGA. As described above, influences from sea salt can be considered rather low. In turn, the MARGA might be less sensitive to organic chlorides, as they are likely less water soluble than inorganic chlorides. These explanations would explain the low agreement between the two instruments in case of chloride.

Overall, the comparison of the data measured by the ACSM and MAAP with collocated aerosol instruments showed a good reliability, precision, and in most cases, a good accuracy over the whole campaign, including periods with high and low mass loadings. Therefore, the here obtained chemical composition can be used qualitatively and quantitatively for the source apportionment of aerosol components at this rural site. Major discrepancies to the SMPS especially during some of the pollution events, like 1627 January 2013 and 5-8 May 2013 (see below) can be ex- 


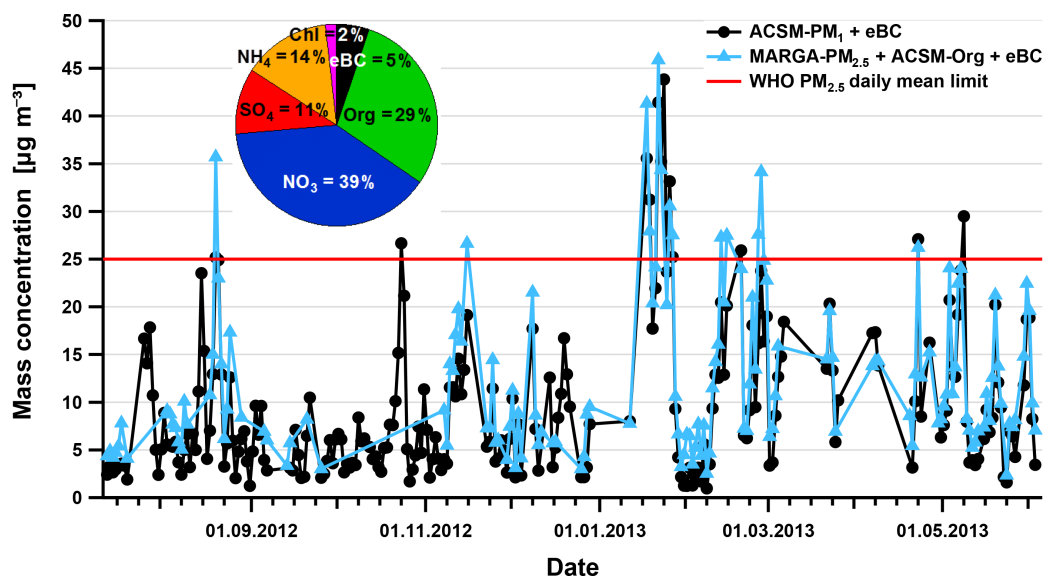

Figure 1. Time series of the daily mean. The black line represents the sum of eBC and all ACSM species, the blue line the sum of eBC, ACSM organics, and all MARGA $\mathrm{PM}_{2.5}$ species. The pie chart shows the fractional abundances of individual eBC and ACSM species averaged over the whole campaign. For the determination of the daily means, missing eBC data were filled with zero values, thus deriving lower concentration limits.

plained by the correction of losses through the $60 \mathrm{~m}$ inlet line which was done size dependently and did not account for losses of individual species as mentioned in Sect. 2.3. Furthermore, discrepancies can also result from the different sampling heights of the SMPS and MAAP (both at $60 \mathrm{~m}$ ) and ACSM and MARGA (both $5 \mathrm{~m}$ ), through which the instruments might have sampled partly within different layers with different mass concentrations. As the quantitative agreements of individual inorganic species as well as of total inorganics between the ACSM and the MARGA during these periods are much higher, the mass loadings determined from these instruments are more reliable than the SMPS data.

\subsection{Aerosol chemical composition}

A meteorological overview of this campaign, including wind direction, precipitation, radon 222 measurements, and ambient temperature and relative humidity $(\mathrm{RH})$ is provided in Fig. S7. Table S1 in the Supplement shows temperature and $\mathrm{RH}$ values averaged over selected periods (see below). If not stated otherwise, all data shown in this chapter are in UTC (local time minus 1 or $2 \mathrm{~h}$, respectively) and averaged and synchronized to the ACSM data resolution of $30 \mathrm{~min}$. Summing up the ACSM and MAAP data, a total mass concentration of $9.5 \mu \mathrm{g} \mathrm{m}^{-3}$ was measured on average, with a maximum of $78.4 \mu \mathrm{g} \mathrm{m}^{-3}$ and a minimum of $0.2 \mu \mathrm{g} \mathrm{m}^{-3}$.

Data coverage of $75 \%$ for 1 day and $90 \%$ for 1 calendar year, respectively, is defined mandatory for a proper risk assessment according to the WHO air quality guideline. The last requirement could not be achieved with the ACSM nor with the MARGA between July 2012 and June 2013 (70 and $71 \%$ coverage, respectively). Nevertheless, the average total mass derived from the combination of the MARGA $\mathrm{PM}_{2.5}$ data (including all water-soluble inorganic components $\mathrm{NO}_{3}, \mathrm{NH}_{4}, \mathrm{SO}_{4}, \mathrm{Cl}, \mathrm{Na}, \mathrm{K}, \mathrm{Mg}$, and $\mathrm{Ca}$ ), MAAP
eBC and ACSM PM $\mathrm{PM}_{1}$ organics resulted in $12.5 \mu \mathrm{g} \mathrm{m}^{-3}$ during this time, clearly exceeding the WHO $\mathrm{PM}_{2.5}$ annual mean limit $\left(10 \mu \mathrm{g} \mathrm{m}^{-3}\right)$ by $25 \%$. Even the $\mathrm{PM}_{1}$ concentration inferred from ACSM plus MAAP data (campaign average $9.5 \mu \mathrm{g} \mathrm{m}^{-3}$ ) approached the WHO $\mathrm{PM}_{2.5}$ limit.

The time series of the daily mean total mass derived from both combinations (MARGA $\mathrm{PM}_{2.5}$ plus ACSM organics plus $\mathrm{eBC}$, and total ACSM plus $\mathrm{eBC}$ ), where the required data coverage of $75 \%$ was reached, are shown in Fig. 1. The WHO $\mathrm{PM}_{2.5}$ daily mean limit of $25 \mu \mathrm{g} \mathrm{m}^{-3}$ was exceeded on 17 and 12 days, respectively. There were 8 and 7 exceedances observed during a period with high pollution from 16 to 27 January 2013 , respectively.

In Fig. 2, the average contributions of individual species are shown as (a) pie charts and (b) stacked time series. A technical problem of the MAAP instrument was responsible for the lack of BC data from 15 February to 25 April 2013. To properly determine average species contributions for each pie chart, the campaign was therefore not divided strictly by season, but into five periods. The first two sections represent the summer (July-August-September) and autumn (October-November-December) 2012, while the first half of 2013 was divided into periods with and without BC data. Larger gaps in ACSM data occurred mainly due to problems with the RGA detector, in addition to minor measurement gaps for maintenance and calibrations.

Overall, particulate nitrate and organics were the dominant species, representing 39 and $29 \%$ of the total aerosol, respectively. Both compounds show similar contributions in summer (period 1) and autumn 2012 (period 2), whereas in winter (January-February-March, period 3 and beginning of period 4) and spring (April-May-June, periods 4 and 5) the $\mathrm{NO}_{3}$ fraction increased up to an average of $46 \%$ of the total particulate mass, and the organic and $\mathrm{eBC}$ fractions de- 


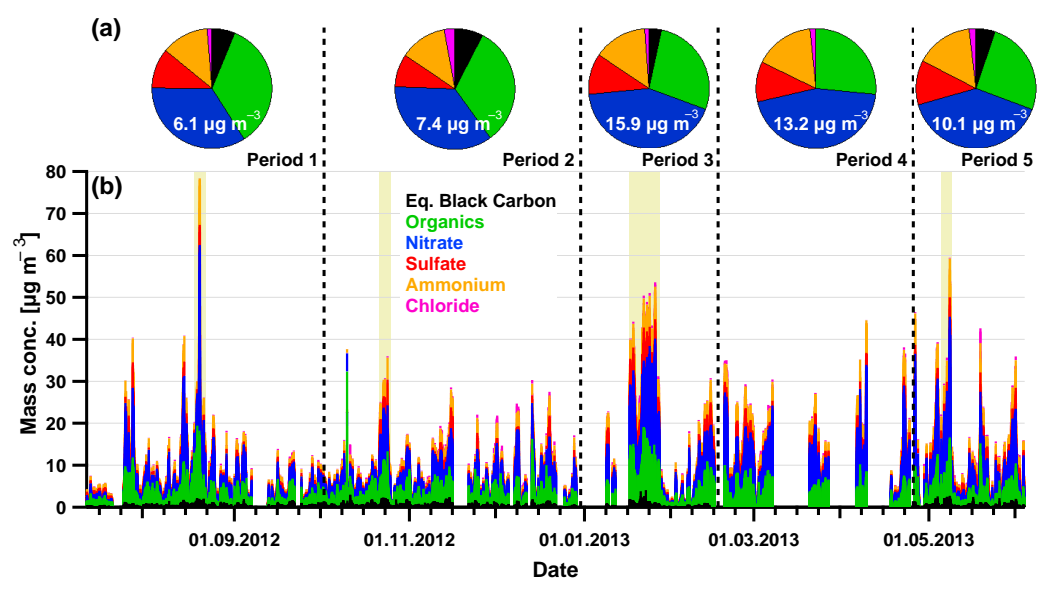

Figure 2. Overview of the ACSM campaign. (a) Pie charts of average fractional abundances of aerosol species, separated in five periods. The respective average total mass concentration is written inside the pie chart. (b) Stacked time series of mass concentrations of aerosol species. Pollution events are indicated by shaded areas.

creased. The contributions of the other components showed only small variations between the seasons (see Table S2).

The most significant pollution events (17-21 August 2012, 21-25 October 2012, 16-27 January 2013, and 5-8 May 2013) are highlighted with shaded backgrounds in Fig. 2. During these events, MARGA $P_{2.5}$ data showed up to $33 \%$ higher (e.g., from 17 to 21 August 2012) total inorganic masses than ACSM $\mathrm{PM}_{1}$ inorganics as implicated in Fig. 1. As mentioned above, the number and proportions of exceedances of the WHO $\mathrm{PM}_{2.5}$ daily mean limit is therefore even higher than when only $\mathrm{PM}_{1}$ data are considered. During the last three events, northerly and northeasterly winds dominated. The period 16-27 January 2013 showed also the lowest temperatures (average: $-4^{\circ} \mathrm{C}$ ) with respect to the whole campaign and a temperature inversion between 2 and $40 \mathrm{~m}$ height on the morning of 25 January 2013, where both instruments showed total mass concentrations of ca. $20 \mu \mathrm{g} \mathrm{m}^{-3}$. On the other hand, no temperature inversion was seen during times when very high $\left(>40 \mu \mathrm{g} \mathrm{m}^{-3}\right)$ aerosol mass loadings were observed, even in wintertime. Many sudden drops of the particulate mass can be either explained by changes in wind direction and/or precipitation events, like in case of the two latter pollution events (16 to 27 January 2013, and 5 to 8 May 2013).

Figure 3 shows the diurnal patterns of each individual species and the total particulate mass for the whole campaign. Corresponding plots with data averaged separately for the five chosen periods can be found in the Supplement (Fig. S8). Overall, $\mathrm{NO}_{3}$ showed the largest diurnal variation, with a maximum during the night/morning hours, reflecting its nighttime production and a minimum during the day due to the volatility of $\mathrm{NH}_{4} \mathrm{NO}_{3}$. This pattern is more pronounced in the warmer periods 1 and 5 . Since the majority of ammonium is originated from $\mathrm{NH}_{4} \mathrm{NO}_{3}, \mathrm{NH}_{4}$ has a similar pattern to that of $\mathrm{NO}_{3} . \mathrm{SO}_{4}$, which is mainly formed photochemi-

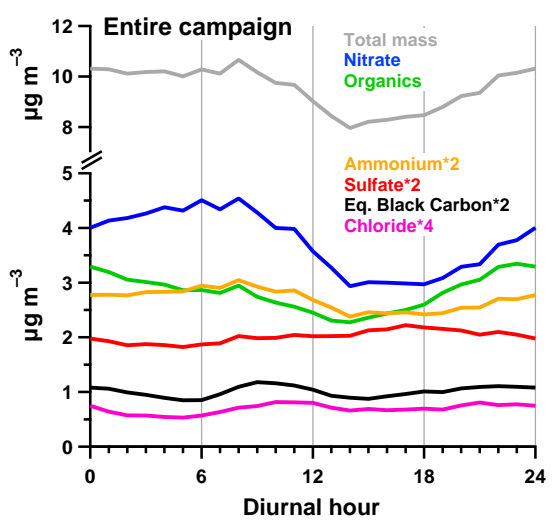

Figure 3. Diurnal variation (local time, LT) of individual species and the total mass, averaged over the whole ACSM campaign.

cally during the day from gaseous $\mathrm{SO}_{2}$, showed peaks during daytime, although its overall variation is rather low. The maxima of $\mathrm{BC}$ can be attributed to direct emissions from traffic (morning and evening rush hours) and biomass burning events (domestic heating in the evenings/nights). Finally, OA showed peaks at the evening hours during the colder periods and a daytime minimum during the summer. More detailed discussion of the diurnal patterns of individual OA factors is given below.

An ion balance of all inorganic compounds indicates that too little $\mathrm{NH}_{4}$ was measured to neutralize all $\mathrm{NO}_{3}$ and $\mathrm{SO}_{4}$ to their corresponding ammonium salts. The measured $\mathrm{NH}_{4}$ mass concentration against the predicted $\mathrm{NH}_{4}$ from the ion balance is plotted in the Supplement (Fig. S9) and resulted in a slope of $0.83 \pm 0.00$. One uncertainty of the ion balance is introduced by the use of RIEs for the inorganic species. As shown below, we consider uncertainties of RIEs to be of minor importance in explaining the observed low particulate 
$\mathrm{NH}_{4}$ concentration. It should be noted that for the calculation of the ion balance all measured $\mathrm{NO}_{3}$ is considered. In addition to $\mathrm{NH}_{4} \mathrm{NO}_{3}$, organic nitrates give rise to a nitrate signal in the AMS, albeit with distinct difference in relative ion abundance (Alfarra et al., 2004; Fry et al., 2011, 2009). It was not possible to distinguish the organic and inorganic nitrate fraction based on their mass spectra with the ACSM. Since a relatively high amount of particulate organic nitrates was found in previous campaigns at CESAR using an AMS (Mensah, 2011), and the region is characterized by high $\mathrm{NH}_{3}$ emissions (Derksen et al., 2011), the potential contribution of organic nitrates to the gap in the ion balance was explored as follows.

In contrast to the ion balance from the ACSM data, MARGA $\mathrm{PM}_{1}$ measurements during the whole campaign showed a nearly $1: 1$ correlation of measured-to-predicted $\mathrm{NH}_{4}$ (slope of the linear regression line: $1.03 \pm 0.00$, Pearson $R^{2}=0.97$ ), but with a negative offset of ca. $0.30 \pm 0.01 \mu \mathrm{g} \mathrm{m}^{-3}$. This offset, which is at least 3 times higher than the detection limits of the MARGA, cannot be explained by including positive metal ions to the ion balance since the sum of $\mathrm{Mg}, \mathrm{Na}, \mathrm{K}$, and $\mathrm{Ca}$ mass concentrations had low contribution to particulate mass as mentioned in Sect. 3.1. Thus, significant influence of their nitrate salts to total nitrate can be excluded. In addition, as the MARGA is measuring the water-soluble nitrate fraction, the MARGA $\mathrm{NO}_{3}$ can be considered to be exclusively $\mathrm{NH}_{4} \mathrm{NO}_{3}$. This assumption is acceptable, as shown by using the MARGA NO instead of the ACSM total $\mathrm{NO}_{3}$ for the ion balance of ACSM data (including ACSM SO 4 , $\mathrm{Chl}$, and $\mathrm{NH}_{4}$ ), following a procedure given by Xu et al. (2015), who calculated the organic nitrate fraction by subtracting the inorganic nitrate concentrations measured by a particle-into-liquid sampler (PILS, see Orsini et al., 2003) from ToF-AMS total nitrate concentrations. In the Cabauw data set, the correlation of measuredto-predicted $\mathrm{NH}_{4}$ resulted in a nearly $1: 1$ regression line without a significant offset (Fig. S10). This is in agreement with the MARGA internal ion balance which also indicates neutralized inorganic aerosols. Therefore, the mass concentration of nitrate groups associated with organic molecules (hereafter called organic nitrate or $\mathrm{OrgNO}_{3}$ ), can be estimated by subtracting the MARGA nitrate from the ACSM nitrate concentration. The $\mathrm{OrgNO}_{3}$ time series using this approach is plotted in Fig. S11; the respective diurnal variations averaged over for each period and for the entire campaign are presented in Fig. S12. An average mass fraction of $9 \%$ was calculated for $\mathrm{OrgNO}_{3}$ (average concentration: $0.43 \mu \mathrm{g} \mathrm{m}^{-3}$ ) in respect to total ACSM NO $\mathrm{N}_{3}$. Note that the organic nitrate concentrations may be biased low considering that, although the nitrate concentrations of both instruments are considered $\mathrm{PM}_{1}$, the transmission efficiency of the ACSM decreases for particles with diameters between ca. $800 \mathrm{~nm}$ and $1 \mu \mathrm{m}$. This may also explain the slightly negative $\mathrm{OrgNO}_{3}$ values seen in Fig. S11. The organic nitrate fraction shows a maximum concentration at night for nearly all individual periods and for the whole campaign, followed by a decrease during the day. Particulate organic nitrates found in this study may therefore be considered as mainly semi-volatile as the evaporation from particles is dominating during warmer daytime hours. Due to the low temperatures within period 3, evaporation is less important during this time as seen by the daytime maximum. These findings are in agreement with previously reported relatively high AMS organic nitrate fractions by Mensah (2011) in May $2008\left(0.5 \mathrm{\mu g} \mathrm{m}^{-3}, 35 \%\right.$ of total nitrate, $5.2 \%$ of total aerosol mass) and March $2009\left(0.2 \mu \mathrm{g} \mathrm{m}^{-3}, 10 \%\right.$ of total nitrate, $3.6 \%$ of total aerosol mass) in Cabauw.

\subsection{Factor analysis of organic aerosols}

Prior to PMF analysis, the ACSM data set was subdivided into four data sets, which were explored by PMF separately, mainly due to the operational time of the ACSMs that are in the following referred to as (i) July-AugustSeptember 2012: summer 2012; (ii) October-NovemberDecember 2012: autumn 2012; (iii) January-FebruaryMarch 2013: winter 2013; (iv) April-May-beginning of June 2013: spring 2013. A more detailed overview of the selected seasons is given in Table S3.

Figure 4 summarizes the time series of PMF factor classes (two POA factors: HOA and BBOA; and two SOA factors: OOA and a humic-like substance (HULIS) related factor, see below for descriptions) found for all seasons, except for BBOA in summer 2012. A corresponding graph dividing these PMF results into the five periods according to Fig. 2 is shown in Fig. S13. The POA profiles were constrained within ME-2 using the HOA and BBOA mass spectra found by ME2 operated PMF analyses by Crippa et al. (2014) at the CESAR tower in Cabauw in March 2009. For the HOA profile, a constant $a$ value of 0.1 was found to be most suitable for every season. If observed, the BBOA $a$ value was set to either 0.2 (autumn 2012) or 0.3 (winter and spring 2013). The $a$ values are based on different sensitivity tests for each season, as described Canonaco et al. (2013). Factor profiles including fractional contributions of marker ions $\left(f_{44}, f_{43}\right.$, and $\left.f_{60}\right)$ and diurnal variations for winter 2013 are displayed in Fig. 5 as a representative example. Corresponding graphs for every season are shown in Figs. S14 and S15, respectively. Table S4 gives an overview of the temporal correlations of each factor with external data sets, while scatter plots from winter 2013 profiles against profiles found in May 2008 at CESAR by Crippa et al. (2014) are given in Fig. S16.

As mentioned, no significant BBOA influence was seen in summer 2012. Thus, a three-factor solution was chosen for this season and consequently, no BBOA time series exist at that time. For all other factors, the time series are continuous on 1 October 2012 (i.e., analysis of separate data files leads to a consistent result in terms of both factor profiles and concentrations). The SOA factors showed always higher contribution (54-84\%, averaged by season) to total organics compared to POA (16-46\%). For all PMF factors, no preferential 


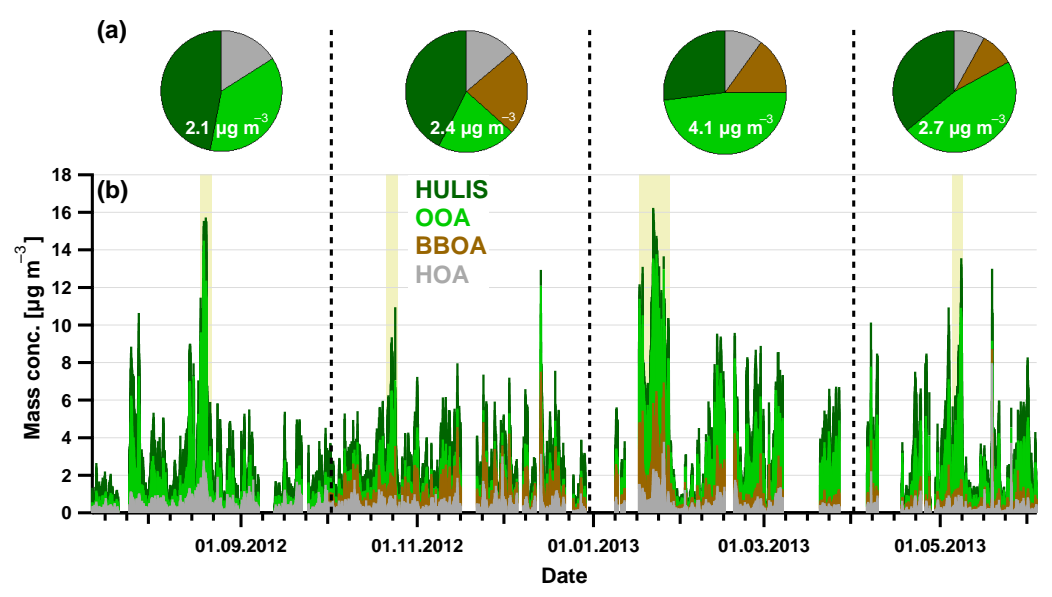

Figure 4. Overview of ACSM PMF factors. (a) Seasonal pie charts of the factor contributions. The respective average total organic concentration is written inside the pie chart. (b) Stacked time series of mass concentrations. Shaded areas represent highly polluted events.

wind direction was observed over the entire campaign. During the pollution events mentioned above, OOA originated mostly from the directions between 20 and $180^{\circ}$ in respect to the tower. This is not the case for HULIS, the origins of which varied throughout all directions also during pollution events.

The seasonal average HOA contribution to total organic mass was highest in summer 2012 and lowest in spring 2013 (16 and $8 \%$, respectively). All HOA diurnal patterns (Fig. 5b) showed a maximum at 07:00 and 11:00 (LT) and a slight increase in the evening, emphasizing that its main source is related to traffic likewise to BC (see Sect. 3.1). In winter 2013, these maxima were less distinctive comparing to the other seasons. Highest temporal agreements with HOA were seen by the POA tracers $\mathrm{BC}, \mathrm{NO}_{x}$, and $\mathrm{CO}\left(R^{2}=0.38\right.$, 0.47 , and 0.47 , respectively) over the entire campaign.

The BBOA profile showed a very high contribution of $m / z 60$, which is dominated by the $\mathrm{C}_{2} \mathrm{H}_{4} \mathrm{O}_{2}^{+}$ion. This fragment is characteristic for anhydrosugars such as levoglucosan (Alfarra et al., 2007), which are established markers of wood combustion processes (Simoneit and Elias, 2001; Simoneit et al., 1999). The fractions of $m / z 60$ to the BBOA profile in autumn $2012(3.7 \%)$ and winter $2013(3.2 \%)$ are higher than in spring $2013(2.4 \%)$. As mentioned, BBOA was not found in summer 2012. This was verified by the fact that the contribution of $m / z 60$ to the BBOA profile decreases for higher $a$ values in that season, which is an indication for the nonexistence of BBOA. The highest contributions of BBOA to total organics were seen in the colder autumn $(23 \%)$ and winter seasons $(15 \%)$. This and the diurnal maximum during the evenings and nights match the expectations for a factor linked with domestic heating activities, together with the fact that this factor was not seen during the warmer summer season. Averaged over the whole campaign, the contribution to total organics was $13 \%$, including summer 2012, where its fraction was set to 0 . In winter, the cor- relations with eBC and $\mathrm{CO}$ were higher $\left(R^{2}=0.64\right.$ and 0.57 , respectively) than over the whole campaign $\left(R^{2}=0.39\right.$ and 0.49 , respectively), meaning that these compounds are reasonably more attributed to domestic heating during the colder periods compared to the contribution of heating to $\mathrm{BC}$ and $\mathrm{CO}$ during the other seasons in this region.

The OOA profile is similar to a MS pattern as expected for a low-volatile OOA (LVOOA) factor. The correlation coefficients (Pearson $R^{2}$ ) with the OOA and LVOOA spectra given by $\mathrm{Ng}$ et al. (2011a) are 0.94 and 0.97 , respectively. Similar agreement was found compared to the LVOOA factor observed by Mensah (2011) and Crippa et al. (2014) $\left(R^{2}=0.97\right.$ and 0.94 , respectively) at the CESAR tower in May 2008. The OOA factor showed a nighttime maximum and a daytime minimum. This is rather characteristic for a semi-volatile OOA (SVOOA) behavior, as well as the high agreement with $\mathrm{NO}_{3}$ over the whole year $\left(R^{2}=0.63\right)$, as described by Lanz et al. (2007). The correlation to the LVOOA-associated compound $\mathrm{SO}_{4}$ is less significant $\left(R^{2}=\right.$ 0.48 ). OOA dominated the organic fraction in winter and spring 2013 (47 and 48\% contribution, respectively; 33\% over the whole year). During the defined pollution events the increase of the OOA mass concentration (up to $11.8 \mu \mathrm{g} \mathrm{m}^{-3}$ ), relative to the campaign average $\left(1.05 \mu \mathrm{g} \mathrm{m}^{-3}\right)$, is much stronger compared to the other PMF factors, demonstrating that this factor is mainly responsible the high total OA mass during these periods.

The so-called HULIS factor showed the highest $f_{44}$ values of all factors, increasing from summer 2012 to spring 2013 from 0.23 to 0.35 . The HULIS factor class was first observed by Mensah (2011) in previous AMS campaigns at the CESAR tower in May 2008 and March 2009. The identification and characterization of this factor class was done in the 2008 campaign by the comparison with data from an ionexchange chromatographic method for direct quantification of humic-like substances (HULIS) and from water-soluble 

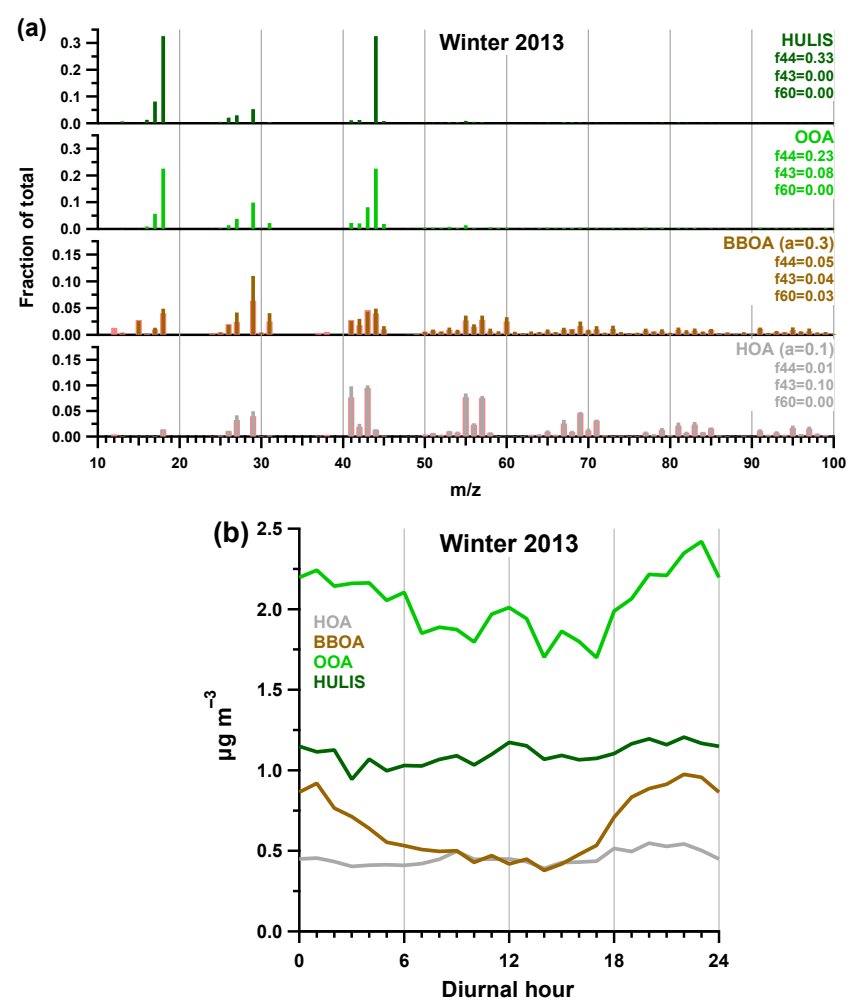

Figure 5. (a) Mass spectra of ACSM PMF factors and (b) average diurnal variations (LT) of ACSM factors found in winter 2013. For the constrained profiles HOA and BBOA, the applied $a$ value is written in brackets. Corresponding reference spectra are shown by red bars. Note that the $y$ axis scales of the POA profiles are zoomed by a factor of 2 compared to SOA profiles.

organic carbon (WSOC) analyzed offline on a set of filters collected in parallel (Paglione et al., 2014). The HULIS factor provided the highest contribution to the total organic mass over the entire campaign ( $41 \%$ ) and was the dominant factor in summer and autumn 2012. Since it had no distinct diurnal variation and preferential wind direction, it can be considered as a regional background aerosol at this rural site. Additionally, the variation between the seasonal average concentrations of HULIS within the ACSM data set is less than $\pm 10 \%$. Also the comparison to the most important tracers (Table S4 in the Supplement) showed no preferential attribution, either to a low-volatile $\left(R^{2}=0.41\right.$ with $\left.\mathrm{SO}_{4}\right)$, semivolatile $\left(R^{2}=0.39\right.$ with $\left.\mathrm{NO}_{3}\right)$, or primary organic aerosol $\left(R^{2}=0.47\right.$ with $\left.\mathrm{eBC}\right)$. These characteristics were also reported for the HULIS factor found at CESAR in May 2008 (Crippa et al., 2014; Mensah, 2011). The correlation of the sum of the secondary inorganic species $\mathrm{NO}_{3}$ and $\mathrm{SO}_{4}$ with the sum of the OOA and HULIS time series gives a coefficient of $R^{2}=0.70$, which is slightly higher than with OOA only $\left(R^{2}=0.67\right)$. This might confirm the SOA character of the HULIS factor. The reason why HULIS was the dominant factor in summer and autumn 2012 is due to the lower mass concentrations of the other factors compared to the remaining periods. In turn, OA mass increased during pollution events mainly due to the increase of the other SOA factor, namely OOA. A number of studies are published with different theories on the formation and sources of atmospheric HULIS. It shows similarities to terrestrial humic acids (HA) and fulvic acids (FA) due to their (poly-)acidic nature, but with lower molecular weight $(<1000 \mathrm{amu})$ than HA or FA (Graber and Rudich, 2006; Kiss et al., 2003). On the other hand, solid-phase extraction protocols for HULIS associating them with the more hydrophobic fraction of water-soluble aerosols (e.g., Varga et al., 2001). Graber and Rudich (2006) suggested that the formation of HULIS happens by oligomerization of lighter organic acids in liquid droplets in the atmosphere within timescales of hours to days. This emphasizes that HULIS is an ubiquitous background factor at Cabauw, characterized as a regionally well-mixed aerosol of a long atmospheric lifetime.

Note that the correlation coefficient (Pearson $R^{2}$ ) of the POA factors with eBC data is relatively low $\left(R^{2}=0.38\right.$ and 0.39 with HOA and BBOA, respectively), while in turn HULIS shows a higher correlation with $\mathrm{eBC}\left(R^{2}=0.47\right)$ Furthermore, correlation coefficients of the POA factors with $\mathrm{CO}$ and $\mathrm{NO}_{x}$ time series do not exceed values above 0.47 . Low correlations of POA and those tracers, e.g., HOA with $\mathrm{CO}$ or $\mathrm{BC}$ varying from far below 0.5 to slightly above 0.5 were also seen in a number of previous studies at remote and rural sites (Canonaco et al., 2013; Minguillón et al., 2015; Schmale et al., 2013; Setyan et al., 2012), including Cabauw (Crippa et al., 2014; Mensah et al., 2011). There, low concentrations of POA factors and (e)BC to total aerosol mass were determined and resulted in higher uncertainties for the identification of these factors, likewise in this study. Nevertheless, the correlations of POA factors with $\mathrm{CO}$ and $\mathrm{NO}_{x}$ are still by far higher than the correlation of these tracers with the SOA factors, which, together with the very high agreement of $m / z 60$ with BBOA, underlines the correct identification of HOA and BBOA. The higher correlation of HULIS with eBC can be understood in the light of a study by Andreae and $\mathrm{Ge}$ lencsér (2006), who pointed out that the fiber filters, as used by the MAAP, loaded with macroscopic amounts of humiclike substance samples appear very dark brown or nearly black. A possible interference of HULIS with BC measurements can therefore not be excluded and would explain why the HULIS factor, in contrast to the POA factors, has a relatively high correlation coefficient with $\mathrm{BC}$ data. The use of instruments like an aethalometer or a particle soot absorption photometer as used in other studies would reduce these interferences (Andreae and Gelencsér, 2006; Petzold et al., 2013), but were not available during the campaign. Though given the relatively low contribution of $\mathrm{eBC}$ to total aerosol mass, a possible partial interference with HULIS is of minor importance regarding total aerosol masses.

The source apportionment, as described here, used a data set which was subdivided into the four seasons prior to PMF 

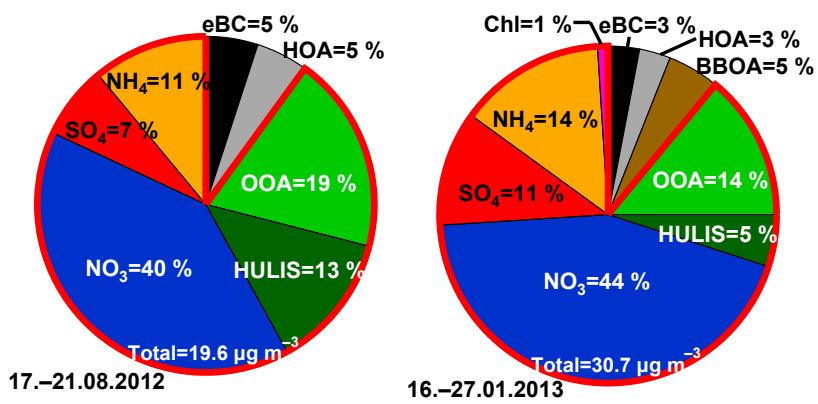

Figure 6. Average contributions of individual aerosol species and PMF factors during selected pollution events. Surrounded red regions represent the secondary aerosol fraction.

analysis. A single PMF analysis of the whole data set with constrained HOA and BBOA profiles led to solutions with a highly overestimated BBOA factor in the summer, compared to the results when the seasons were explored individually (see Fig. S17 and S18 in the Supplement). Furthermore, the contributions of individual factors change significantly in some periods, especially for the OOA factor during pollution events. This is mainly driven by the different OOA $f_{44}$ and $f_{43}$ values. This behavior is independent of applied $a$ values for BBOA and may result from the uncertainty of this statistical tool. Since there was no evidence of BBOA seen in the separate analysis of the summer period (e.g., low fraction of $m / z 60$ in the organic mass spectrum and no correlation of the constrained BBOA factor with POA tracers, no matter which $a$ value was used), the solutions derived from the single PMF analysis were reasonably rejected.

\subsection{Composition and sources of aerosols during pollution events}

The investigation of pollution events showed that the majority of aerosol mass was contributed from secondary aerosols. As an example, Fig. 6 displays average abundances during two selected periods (17-21 August 2012 and 16-27 January 2013), where the organic fraction is further divided into the PMF factors. Nitrate and organics are still the dominant species, while the primary aerosol components (BC, HOA, BBOA) have even less influence than during the entire respective season. An exception is seen from BBOA, the contribution of which is reasonably higher during the latter pollution event with very low temperatures, when domestic heating sources most likely increased. But even at this time, primary organics do not exceed $11 \%$ of total mass on average.

Since the major inorganic components $\mathrm{NH}_{4} \mathrm{NO}_{3}$ and $\left(\mathrm{NH}_{4}\right)_{2} \mathrm{SO}_{4}$ are produced by atmospheric processes, they are considered as secondary aerosols. Together with the high abundance of SOA (OOA, HULIS), chemically aged aerosol components have the largest impact on total particulate mass (up to $90 \%$ ) at Cabauw. The largest effect on a potential reduction of particulate mass can therefore be achieved by reducing $\mathrm{NO}_{x}$ and/or $\mathrm{NH}_{3}$ emissions, the anthropogenic precursors of particulate $\mathrm{NH}_{4}$ and $\mathrm{NO}_{3}$. Indeed, on 16 January 2013, the highest $\mathrm{NO}_{x}$ values were observed compared to the whole campaign (daily mean: $96 \mu \mathrm{g} \mathrm{m}^{-3}$; seasonal average: $29 \mu \mathrm{g} \mathrm{m}^{-3}$ ). Also the highest $\mathrm{NH}_{3}$ values were obtained between 17 and 19 August 2012 (daily means: 26-28 $\mu \mathrm{g} \mathrm{m}^{-3}$; seasonal average: $10 \mu \mathrm{g} \mathrm{m}^{-3}$ ). These ammonia values are higher than previously reported for Cabauw, e.g., by Derksen et al. (2011) in May 2008 (approximately $20 \mu \mathrm{g} \mathrm{m}^{-3}$ ). Lolkema et al. (2015) gave an annual average of $5.3 \mu \mathrm{g} \mathrm{m}^{-3}$ for 2013 in this region.

\section{Conclusions}

This work provides chemical composition data of atmospheric aerosols acquired during 1 year at the CESAR tower in Cabauw, the Netherlands, which is a representative rural site for northwestern Europe. The concentration of submicron particles from combined ACSM and MAAP data showed 12 exceedances from the WHO $\mathrm{PM}_{2.5}$ daily mean limit. The respective campaign average of $9.5 \mu \mathrm{g} \mathrm{m}{ }^{-3}$ approached the WHO $\mathrm{PM}_{2.5}$ annual mean limit. Taking MARGA $\mathrm{PM}_{2.5}$ into account, the number and proportions of these exceedances are even higher, emphasizing the importance of these high $\mathrm{ACSM} \mathrm{PM}_{1}$ results shown here which represent lower limits. As carbonaceous compounds are estimated to be 5 times more toxic than inorganic particles (Lelieveld et al., 2015) MARGA data alone would not give sufficiently possible implications regarding adverse health effects. While few people live in the direct vicinity of the measurement site, the high aerosol concentration measured at the site can be considered to represent the regional background. This regional background is adding to local aerosol contributions in high populated urban sites (Pandis et al., 2013), namely the four largest cities of the Netherlands which have a distance of $40 \mathrm{~km}$ or less from the CESAR tower.

Particulate mass loadings found at this rural site are dominated by secondary aerosol formation through atmospheric gas phase chemistry and particle phase aging. It is shown that particulate ammonium nitrate is the major aerosol component (39\% on average) and represents the more hygroscopic aerosol fraction. Since the human respiratory system is characterized by high humidity, more hygroscopic aerosols have a higher deposition tendency within the human lung than less water-soluble particle compounds (Asgharian, 2004; Broday and Georgopoulos, 2001). With special regard to adverse health effects, this is very crucial because Asgharian (2004) also found that especially hygroscopic submicron particles can deposit in the entire lung. The high ammonium nitrate fraction also implies that inorganic SA reduction in Cabauw can be most efficiently achieved through the reduction of gaseous ammonia emissions in the area. 
As indicated by model results for the southwestern United States from Zhang and $\mathrm{Wu}$ (2013), the reduction of $\mathrm{NH}_{3}$ emissions, in conjunction with already implemented $\mathrm{SO}_{2}$ and $\mathrm{NO}_{x}$ emission reductions, can further reduce $\mathrm{PM}_{2.5}$ than reducing $\mathrm{SO}_{2}$ and $\mathrm{NO}_{x}$ emissions alone, particularly for regions with high emissions of $\mathrm{NH}_{3}$ from agricultural sources. The latter is clearly the case for Cabauw with its high amount of animal husbandry and the use of nitrogen-containing fertilizers around the CESAR tower. Banzhaf et al. (2013) derived similar conclusions for $\mathrm{PM}_{10}$ using different emission scenarios within domains covering Germany and Europe. Applying a 3-D chemical transport model over Europe, Megaritis et al. (2014) found that a reduction of $\mathrm{NH}_{3}$ emissions by $50 \%$ would have a much higher effect on reducing $\mathrm{PM}_{2.5}$ than decreasing $\mathrm{NO}_{x}$ emissions by $50 \%$. The latter scenario would even result in negative side effects, such as higher tropospheric ozone concentrations (especially in summertime $4 \%$ over western Europe and up to $40 \%$ in major urban areas) and higher amounts of particulate sulfate and OA by 8 and $12 \%$, respectively, in winter.

The local mitigation of organic aerosol mass (29\% contribution on average) is more challenging, as secondary organic aerosols are highly abundant at the Cabauw site (74 and $22 \%$ of $\mathrm{OA}$ and total $\mathrm{PM}_{1}$ on average, respectively). The presented data set shows a large and ubiquitous HULIS fraction (37\%) which, based on diurnal patterns and a lack of correlation with wind direction, can be considered as long-range background aerosols formed from atmospheric aging processes. In turn, primary organic aerosols emitted mainly from traffic and biomass burning (12 and $13 \%$ of OA on average) have only minor importance. For a more detailed identification of the SOA sources, compound-specific measurements of OA as well as routine VOC monitoring are needed.

Finally, the presented data set and interpretations provide an important contribution to the EU-FP7-ACTRIS project which supported building of new knowledge as well as policy issues on climate change, air quality, and long-range transport of pollutants on a European scale.

\section{Data availability}

The observational data in this study from ACSM and SMPS instruments are available on the EBAS database: http://ebas. nilu.no (Schlag et al., 2015; Henzing and Moerman, 2015). MAAP data can be accessed by request to J. S. Henzing (TNO). MARGA data can be accessed by request to Rene Otjes $(\mathrm{ECN})$.

The Supplement related to this article is available online at doi:10.5194/acp-16-8831-2016-supplement.
Acknowledgements. The research leading to these results has received funding from the European Union Seventh Framework Programme (FP7/2007-2013) under grant agreement no. 262254. We appreciate the support from KNMI in hosting the experiment at Cabauw and for the access to meteorological data from the tower. The authors thank the CESAR tower team for the big support during the campaign, as well as RIVM for providing $\mathrm{CO}, \mathrm{NO}_{x}$, and $\mathrm{O}_{3}$ data. Additionally, the authors appreciate measurements of ambient $\mathrm{CO}_{2}$ and radon $222\left({ }^{222} \mathrm{Rn}\right)$ done by ECN. We also thank Philip Croteau (Aerodyne Research) for his support during the measurements regarding the data acquisition and evaluation.

The article processing charges for this open-access

publication were covered by a Research

Centre of the Helmholtz Association.

Edited by: A. Huffman

Reviewed by: four anonymous referees

\section{References}

Alfarra, M. R., Coe, H., Allan, J. D., Bower, K. N., Boudries, H., Canagaratna, M. R., Jimenez, J. L., Jayne, J. T., Garforth, A. A., Li, S.-M., and Worsnop, D. R.: Characterization of urban and rural organic particulate in the Lower Fraser Valley using two Aerodyne Aerosol Mass Spectrometers, Atmos. Environ., 38, 5745-5758, 2004.

Alfarra, M. R., Prevot, A. S. H., Szidat, S., Sandradewi, J., Weimer, S., Lanz, V. A., Schreiber, D., Mohr, M., and Baltensperger, U.: Identification of the mass spectral signature of organic aerosols from wood burning emissions, Environ. Sci. Technol., 41, 57705777, 2007.

Allan, J. D., Delia, A. E., Coe, H., Bower, K. N., Alfarra, M. R., Jimenez, J. L., Middlebrook, A. M., Drewnick, F., Onasch, T. B., Canagaratna, M. R., Jayne, J. T., and Worsnop, D. R.: A generalised method for the extraction of chemically resolved mass spectra from Aerodyne Aerosol Mass Spectrometer data, J. Aerosol Sci., 35, 909-922, 2004.

Andreae, M. O. and Gelencsér, A.: Black carbon or brown carbon? The nature of light-absorbing carbonaceous aerosols, Atmos. Chem. Phys., 6, 3131-3148, doi:10.5194/acp-6-3131-2006, 2006.

ARI: Aerosol Chemical Speciation Monitor official webpage, Aerodyne Research, Inc., available at: https://sites.google.com/site/ ariacsm/ (last access: 5 May 2014), 2012.

Asgharian, B.: A Model of Deposition of Hygroscopic Particles in the Human Lung, Aerosol Sci. Tech., 38, 938-947, 2004.

Banzhaf, S., Schaap, M., Wichink Kruit, R. J., Denier van der Gon, H. A. C., Stern, R., and Builtjes, P. J. H.: Impact of emission changes on secondary inorganic aerosol episodes across Germany, Atmos. Chem. Phys., 13, 11675-11693, doi:10.5194/acp13-11675-2013, 2013.

Bond, T. C. and Bergstrom, R. W.: Light absorption by carbonaceous particles: an investigative review, Aerosol Sci. Tech., 40, 27-67, 2006.

Bond, T. C., Doherty, S. J., Fahey, D. W., Forster, P. M., Berntsen, T., DeAngelo, B. J., Flanner, M. G., Ghan, S., Kärcher, B., Koch, D., Kinne, S., Kondo, Y., Quinn, P. K., Sarofim, M. C., Schultz, 
M. G., Schulz, M., Venkataraman, C., Zhang, H., Zhang, S., Bellouin, N., Guttikunda, S. K., Hopke, P. K., Jacobson, M. Z., Kaiser, J. W., Klimont, Z., Lohmann, U., Schwarz, J. P., Shindell, D., Storelvmo, T., Warren, S. G., and Zender, C. S.: Bounding the role of black carbon in the climate system: A scientific assessment, J. Geophys. Res.-Atmos., 118, 5380-5552, 2013.

Broday, D. M. and Georgopoulos, P. G.: Growth and Deposition of Hygroscopic Particulate Matter in the Human Lungs, Aerosol Sci. Tech., 34, 144-159, 2001.

Budisulistiorini, S. H., Canagaratna, M. R., Croteau, P. L., Baumann, K., Edgerton, E. S., Kollman, M. S., Ng, N. L., Verma, V., Shaw, S. L., Knipping, E. M., Worsnop, D. R., Jayne, J. T., Weber, R. J., and Surratt, J. D.: Intercomparison of an Aerosol Chemical Speciation Monitor (ACSM) with ambient fine aerosol measurements in downtown Atlanta, Georgia, Atmos. Meas. Tech., 7, 1929-1941, doi:10.5194/amt-7-1929-2014, 2014.

Canagaratna, M. R., Jayne, J. T., Jimenez, J. L., Allan, J. D., Alfarra, M. R., Zhang, Q., Onasch, T. B., Drewnick, F., Coe, H., Middlebrook, A., Delia, A., Williams, L. R., Trimborn, A. M., Northway, M. J., DeCarlo, P. F., Kolb, C. E., Davidovits, P., and Worsnop, D. R.: Chemical and microphysical characterization of ambient aerosols with the Aerodyne Aerosol Mass Spectrometer, Mass Spectrom. Rev., 26, 185-222, 2007.

Canonaco, F., Crippa, M., Slowik, J. G., Baltensperger, U., and Prévôt, A. S. H.: SoFi, an IGOR-based interface for the efficient use of the generalized multilinear engine (ME-2) for the source apportionment: ME-2 application to aerosol mass spectrometer data, Atmos. Meas. Tech., 6, 3649-3661, doi:10.5194/amt6-3649-2013, 2013.

Canonaco, F., Slowik, J. G., Baltensperger, U., and Prévôt, A. S. H.: Seasonal differences in oxygenated organic aerosol composition: implications for emissions sources and factor analysis, Atmos. Chem. Phys., 15, 6993-7002, doi:10.5194/acp-15-69932015, 2015.

Crenn, V., Sciare, J., Croteau, P. L., Verlhac, S., Fröhlich, R., Belis, C. A., Aas, W., Äijälä, M., Alastuey, A., Artiñano, B., Baisnée, D., Bonnaire, N., Bressi, M., Canagaratna, M., Canonaco, F., Carbone, C., Cavalli, F., Coz, E., Cubison, M. J., Esser-Gietl, J. K., Green, D. C., Gros, V., Heikkinen, L., Herrmann, H., Lunder, C., Minguillón, M. C., Mocnik, G., O’Dowd, C. D., Ovadnevaite, J., Petit, J.-E., Petralia, E., Poulain, L., Priestman, M., Riffault, V., Ripoll, A., Sarda-Estève, R., Slowik, J. G., Setyan, A., Wiedensohler, A., Baltensperger, U., Prévôt, A. S. H., Jayne, J. T., and Favez, O.: ACTRIS ACSM intercomparison - Part 1: Reproducibility of concentration and fragment results from 13 individual Quadrupole Aerosol Chemical Speciation Monitors (Q-ACSM) and consistency with co-located instruments, Atmos. Meas. Tech., 8, 5063-5087, doi:10.5194/amt-8-5063-2015, 2015.

Crippa, M., Canonaco, F., Lanz, V. A., Äijälä, M., Allan, J. D., Carbone, S., Capes, G., Ceburnis, D., Dall'Osto, M., Day, D. A., DeCarlo, P. F., Ehn, M., Eriksson, A., Freney, E., Hildebrandt Ruiz, L., Hillamo, R., Jimenez, J. L., Junninen, H., Kiendler-Scharr, A., Kortelainen, A.-M., Kulmala, M., Laaksonen, A., Mensah, A. A., Mohr, C., Nemitz, E., O’Dowd, C., Ovadnevaite, J., Pandis, S. N., Petäjä, T., Poulain, L., Saarikoski, S., Sellegri, K., Swietlicki, E., Tiitta, P., Worsnop, D. R., Baltensperger, U., and Prévôt, A. S. H.: Organic aerosol components derived from 25 AMS data sets across Europe using a consistent ME-2 based source apportionment approach, Atmos. Chem. Phys., 14, 61596176, doi:10.5194/acp-14-6159-2014, 2014.

DeCarlo, P. F., Kimmel, J. R., Trimborn, A., Northway, M. J., Jayne, J. T., Aiken, A. C., Gonin, M., Fuhrer, K., Horvath, T., Docherty, K. S., Worsnop, D. R., and Jimenez, J. L.: Field-deployable, High-Resolution, Time-of-Flight Aerosol Mass Spectrometer, Anal. Chem., 78, 8281-8289, 2006.

Derksen, J. W. B., Roelofs, G.-J. H., Otjes, R., de Leeuw, G., and Röckmann, T.: Impact of ammonium nitrate chemistry on the AOT in Cabauw, the Netherlands, Atmos. Environ., 45, 5640 5646, 2011.

EU: Directive 2008/50/EC of the European Parliament and of the Council of 21 May 2008 on ambient air quality and cleaner air for Europe (OJ L 152, 11 June 2008, p. 1-44), European Union, available at: http://eur-lex.europa.eu/LexUriServ/ LexUriServ.do?uri=OJ:L:2008:152:0001:0044:EN:PDF (last access: 23 June 2014), 2008.

Farmer, D. K., Matsunaga, A., Docherty, K. S., Surratt, J. D., Seinfeld, J. H., Ziemann, P. J., and Jimenez, J. L.: Response of an Aerosol Mass Spectrometer to organonitrates and organosulfates and implications for atmospheric chemistry, P. Natl. Acad. Sci. USA, 107, 6670-6675, 2010.

Finlayson-Pitts, B. J. and Pitts, J. N.: Chemistry of the upper and lower atmosphere - theory, experiments and applications, Academic Press, London, UK, 2000.

Fröhlich, R., Crenn, V., Setyan, A., Belis, C. A., Canonaco, F., Favez, O., Riffault, V., Slowik, J. G., Aas, W., Aijälä, M., Alastuey, A., Artiñano, B., Bonnaire, N., Bozzetti, C., Bressi, M., Carbone, C., Coz, E., Croteau, P. L., Cubison, M. J., Esser-Gietl, J. K., Green, D. C., Gros, V., Heikkinen, L., Herrmann, H., Jayne, J. T., Lunder, C. R., Minguillón, M. C., Mocnik, G., O’Dowd, C. D., Ovadnevaite, J., Petralia, E., Poulain, L., Priestman, M., Ripoll, A., Sarda-Estève, R., Wiedensohler, A., Baltensperger, U., Sciare, J., and Prévôt, A. S. H.: ACTRIS ACSM intercomparison - Part 2: Intercomparison of ME-2 organic source apportionment results from 15 individual, co-located aerosol mass spectrometers, Atmos. Meas. Tech., 8, 2555-2576, doi:10.5194/amt8-2555-2015, 2015.

Fry, J. L., Kiendler-Scharr, A., Rollins, A. W., Wooldridge, P. J., Brown, S. S., Fuchs, H., Dubé, W., Mensah, A., dal Maso, M., Tillmann, R., Dorn, H.-P., Brauers, T., and Cohen, R. C.: Organic nitrate and secondary organic aerosol yield from $\mathrm{NO}_{3}$ oxidation of $\beta$-pinene evaluated using a gas-phase kinetics/aerosol partitioning model, Atmos. Chem. Phys., 9, 14311449, doi:10.5194/acp-9-1431-2009, 2009.

Fry, J. L., Kiendler-Scharr, A., Rollins, A. W., Brauers, T., Brown, S. S., Dorn, H.-P., Dubé, W. P., Fuchs, H., Mensah, A., Rohrer, F., Tillmann, R., Wahner, A., Wooldridge, P. J., and Cohen, R. C.: SOA from limonene: role of $\mathrm{NO}_{3}$ in its generation and degradation, Atmos. Chem. Phys., 11, 3879-3894, doi:10.5194/acp-113879-2011, 2011.

Goldstein, A. H. and Galbally, I. E.: Known and unexplored organic constituents in the earth's atmosphere, Environ. Sci. Technol., 41, 1514-1521, 2007.

Graber, E. R. and Rudich, Y.: Atmospheric HULIS: How humic-like are they? A comprehensive and critical review, Atmos. Chem. Phys., 6, 729-753, doi:10.5194/acp-6-729-2006, 2006.

Guenther, A., Hewitt, C. N., Erickson, D., Fall, R., Geron, C., Graedel, T., Harley, P., Klinger, L., Lerdau, M., Mckay, W. A., 
Pierce, T., Scholes, B., Steinbrecher, R., Tallamraju, R., Taylor, J., and Zimmerman, P.: A global model of natural volatile organic compound emissions, J. Geophys. Res.-Atmos., 100, 8873-8892, 1995.

Guenther, A. B., Jiang, X., Heald, C. L., Sakulyanontvittaya, T., Duhl, T., Emmons, L. K., and Wang, X.: The Model of Emissions of Gases and Aerosols from Nature version 2.1 (MEGAN2.1): an extended and updated framework for modeling biogenic emissions, Geosci. Model Dev., 5, 1471-1492, doi:10.5194/gmd-51471-2012, 2012.

Hallquist, M., Wenger, J. C., Baltensperger, U., Rudich, Y., Simpson, D., Claeys, M., Dommen, J., Donahue, N. M., George, C., Goldstein, A. H., Hamilton, J. F., Herrmann, H., Hoffmann, T., Iinuma, Y., Jang, M., Jenkin, M. E., Jimenez, J. L., Kiendler-Scharr, A., Maenhaut, W., McFiggans, G., Mentel, Th. F., Monod, A., Prévôt, A. S. H., Seinfeld, J. H., Surratt, J. D., Szmigielski, R., and Wildt, J.: The formation, properties and impact of secondary organic aerosol: current and emerging issues, Atmos. Chem. Phys., 9, 5155-5236, doi:10.5194/acp-9-51552009, 2009.

Henzing, J. S.: Interactive comment on: "Number size distributions and seasonality of submicron particles in Europe 2008-2009" by A. Asmi et al., Atmos. Chem. Phys. Discuss., 11, C3137-C3142, 2011.

Henzing, J. S. and Moerman, M.: SMPS particle size distribution data at Cabauw, Zijdeweg (station NL0011R) from 11 July 2012 to 3 June 2013, available at: http://ebas.nilu.no, last access: 26 February 2015.

IPCC: Climate Change 2013: The Physical Science Basis, Contribution of Working Group I to the Fifth Assessment Report of the Intergovernmental Panel on Climate Change, Cambridge University Press, Cambridge, United Kingdom and New York, NY, USA, 2013.

Jayne, J. T., Leard, D. C., Zhang, X. F., Davidovits, P., Smith, K. A., Kolb, C. E., and Worsnop, D. R.: Development of an Aerosol Mass Spectrometer for size and composition analysis of submicron particles, Aerosol Sci. Tech., 33, 49-70, 2000.

Jimenez, J. L., Jayne, J. T., Shi, Q., Kolb, C. E., Worsnop, D. R., Yourshaw, I., Seinfeld, J. H., Flagan, R. C., Zhang, X., Smith, K. A., Morris, J. W., and Davidovits, P.: Ambient aerosol sampling using the Aerodyne Aerosol Mass Spectrometer, J. Geophys. Res.-Atmos., 108, 8425, doi:10.1029/2001JD001213, 2003.

Jimenez, J. L., Canagaratna, M. R., Donahue, N. M., Prevot, A. S. H., Zhang, Q., Kroll, J. H., DeCarlo, P. F., Allan, J. D., Coe, H., Ng, N. L., Aiken, A. C., Docherty, K. S., Ulbrich, I. M., Grieshop, A. P., Robinson, A. L., Duplissy, J., Smith, J. D., Wilson, K. R., Lanz, V. A., Hueglin, C., Sun, Y. L., Tian, J., Laaksonen, A., Raatikainen, T., Rautiainen, J., Vaattovaara, P., Ehn, M., Kulmala, M., Tomlinson, J. M., Collins, D. R., Cubison, M. J., Dunlea, E. J., Huffman, J. A., Onasch, T. B., Alfarra, M. R., Williams, P. I., Bower, K., Kondo, Y., Schneider, J., Drewnick, F., Borrmann, S., Weimer, S., Demerjian, K., Salcedo, D., Cottrell, L., Griffin, R., Takami, A., Miyoshi, T., Hatakeyama, S., Shimono, A., Sun, J. Y., Zhang, Y. M., Dzepina, K., Kimmel, J. R., Sueper, D., Jayne, J. T., Herndon, S. C., Trimborn, A. M., Williams, L. R., Wood, E. C., Middlebrook, A. M., Kolb, C. E., Baltensperger, U., and Worsnop, D. R.: Evolution of organic aerosols in the atmosphere, Science, 326, 1525-1529, 2009.
Kiss, G., Tombacz, E., Varga, B., Alsberg, T., and Persson, L.: Estimation of the average molecular weight of humic-like substances isolated from fine atmospheric aerosol, Atmos. Environ., 37, 3783-3794, 2003.

KNMI: Cesar Database, Royal Netherlands Meteorological Institute (KNMI, the Netherlands), available at: http://www. cesar-database.nl/ (last access: 25 April 2014), 2013.

Lanz, V. A., Alfarra, M. R., Baltensperger, U., Buchmann, B., Hueglin, C., and Prévôt, A. S. H.: Source apportionment of submicron organic aerosols at an urban site by factor analytical modelling of aerosol mass spectra, Atmos. Chem. Phys., 7, 15031522, doi:10.5194/acp-7-1503-2007, 2007.

Lanz, V. A., Alfarra, M. R., Baltensperger, U., Buchmann, B., Hueglin, C., Szidat, S., Wehrli, M. N., Wacker, L., Weimer, S., Caseiro, A., Puxbaum, H., and Prevot, A. S. H.: Source Attribution of Submicron Organic Aerosols during Wintertime Inversions by Advanced Factor Analysis of Aerosol Mass Spectra, Environ. Sci. Technol., 42, 214-220, 2008.

Lelieveld, J., Evans, J. S., Fnais, M., Giannadaki, D., and Pozzer, A.: The contribution of outdoor air pollution sources to premature mortality on a global scale, Nature, 525, 367-371, 2015.

Lolkema, D. E., Noordijk, H., Stolk, A. P., Hoogerbrugge, R., van Zanten, M. C., and van Pul, W. A. J.: The Measuring Ammonia in Nature (MAN) network in the Netherlands, Biogeosciences, 12, 5133-5142, doi:10.5194/bg-12-5133-2015, 2015.

Makkonen, U., Virkkula, A., Mäntykenttä, J., Hakola, H., Keronen, P., Vakkari, V., and Aalto, P. P.: Semi-continuous gas and inorganic aerosol measurements at a Finnish urban site: comparisons with filters, nitrogen in aerosol and gas phases, and aerosol acidity, Atmos. Chem. Phys., 12, 5617-5631, doi:10.5194/acp-125617-2012, 2012.

Megaritis, A. G., Fountoukis, C., and Pandis, S. N.: Sensitivity of fine PM levels in Europe to emissions changes, in: Air Pollution Modeling and its Application XXII, edited by: Steyn, D. G., Builtjes, P. J. H., and Timmermans, R. M. A., Springer, the Netherlands, 333-338, 2014.

Mensah, A. A.: Water and organic nitrate detection in an AMS: Laboratory characterization and application to ambient measurements, Universität zu Köln, 2011.

Mensah, A. A., Buchholz, A., Mentel, T. F., Tillmann, R., and Kiendler-Scharr, A.: Aerosol mass spectrometric measurements of stable crystal hydrates of oxalates and inferred relative ionization efficiency of water, J. Aerosol Sci., 42, 11-19, 2011.

Mensah, A. A., Holzinger, R., Otjes, R., Trimborn, A., Mentel, Th. F., ten Brink, H., Henzing, B., and Kiendler-Scharr, A.: Aerosol chemical composition at Cabauw, The Netherlands as observed in two intensive periods in May 2008 and March 2009, Atmos. Chem. Phys., 12, 4723-4742, doi:10.5194/acp-12-4723-2012, 2012.

Middlebrook, A. M., Bahreini, R., Jimenez, J. L., and Canagaratna, M. R.: Evaluation of composition-dependent collection efficiencies for the Aerodyne Aerosol Mass Spectrometer using field data, Aerosol Sci. Tech., 46, 258-271, 2012.

Minguillón, M. C., Ripoll, A., Pérez, N., Prévôt, A. S. H., Canonaco, F., Querol, X., and Alastuey, A.: Chemical characterization of submicron regional background aerosols in the western Mediterranean using an Aerosol Chemical Speciation Monitor, Atmos. Chem. Phys., 15, 6379-6391, doi:10.5194/acp-15-63792015, 2015. 
Müller, T., Henzing, J. S., de Leeuw, G., Wiedensohler, A., Alastuey, A., Angelov, H., Bizjak, M., Collaud Coen, M., Engström, J. E., Gruening, C., Hillamo, R., Hoffer, A., Imre, K., Ivanow, P., Jennings, G., Sun, J. Y., Kalivitis, N., Karlsson, H., Komppula, M., Laj, P., Li, S.-M., Lunder, C., Marinoni, A., Martins dos Santos, S., Moerman, M., Nowak, A., Ogren, J. A., Petzold, A., Pichon, J. M., Rodriquez, S., Sharma, S., Sheridan, P. J., Teinilä, K., Tuch, T., Viana, M., Virkkula, A., Weingartner, E., Wilhelm, R., and Wang, Y. Q.: Characterization and intercomparison of aerosol absorption photometers: result of two intercomparison workshops, Atmos. Meas. Tech., 4, 245-268, doi:10.5194/amt-4-245-2011, 2011.

Ng, N. L., Canagaratna, M. R., Jimenez, J. L., Zhang, Q., Ulbrich, I. M., and Worsnop, D. R.: Real-time methods for estimating organic component mass concentrations from Aerosol Mass Spectrometer data, Environ. Sci. Technol., 45, 910-916, 2011a.

Ng, N. L., Herndon, S. C., Trimborn, A., Canagaratna, M. R., Croteau, P. L., Onasch, T. B., Sueper, D., Worsnop, D. R., Zhang, Q., Sun, Y. L., and Jayne, J. T.: An Aerosol Chemical Speciation Monitor (ACSM) for routine monitoring of the composition and mass concentrations of ambient aerosol, Aerosol Sci. Tech., 45, 780-794, 2011b.

Orsini, D. A., Ma, Y., Sullivan, A., Sierau, B., Baumann, K., and Weber, R. J.: Refinements to the particle-into-liquid sampler (PILS) for ground and airborne measurements of water soluble aerosol composition, Atmos. Environ., 37, 1243-1259, 2003.

Paatero, P.: Least squares formulation of robust non-negative factor analysis, Chemometr. Intell. Lab., 37, 23-35, 1997.

Paatero, P.: The Multilinear Engine - A table-driven, least squares program for solving multilinear problems, including the n-way parallel factor analysis model, J. Comput. Graph. Stat., 8, 854888, 1999

Paatero, P. and Hopke, P. K.: Discarding or downweighting highnoise variables in factor analytic models, Anal. Chim. Acta, 490, 277-289, 2003.

Paatero, P. and Tapper, U.: Positive Matrix Factorization - a nonnegative factor model with optimal utilization of error-estimates of data values, Environmetrics, 5, 111-126, 1994.

Paglione, M., Kiendler-Scharr, A., Mensah, A. A., Finessi, E., Giulianelli, L., Sandrini, S., Facchini, M. C., Fuzzi, S., Schlag, P., Piazzalunga, A., Tagliavini, E., Henzing, J. S., and Decesari, S.: Identification of humic-like substances (HULIS) in oxygenated organic aerosols using NMR and AMS factor analyses and liquid chromatographic techniques, Atmos. Chem. Phys., 14, 2545, doi:10.5194/acp-14-25-2014, 2014.

Pandis, S. N., Donahue, N. M., Murphy, B. N., Riipinen, I., Fountoukis, C., Karnezi, E., Patoulias, D., and Skyllakou, K.: Introductory lecture: Atmospheric organic aerosols: insights from the combination of measurements and chemical transport models, Faraday Discuss., 165, 9-24, 2013.

Park, K., Kittelson, D., Zachariah, M., and McMurry, P.: Measurement of Inherent Material Density of Nanoparticle Agglomerates, J. Nanopart. Res., 6, 267-272, 2004.

Petzold, A. and Schönlinner, M.: Multi-angle absorption photometry: A new method for the measurement of aerosol light absorption and atmospheric black carbon, J. Aerosol Sci., 35, 421-441, 2004.

Petzold, A., Schloesser, H., Sheridan, P. J., Arnott, W. P., Ogren, J. A., and Virkkula, A.: Evaluation of multiangle absorption photometry for measuring aerosol light absorption, Aerosol Sci. Tech., 39, 40-51, 2005.

Petzold, A., Ogren, J. A., Fiebig, M., Laj, P., Li, S.-M., Baltensperger, U., Holzer-Popp, T., Kinne, S., Pappalardo, G., Sugimoto, N., Wehrli, C., Wiedensohler, A., and Zhang, X.-Y.: Recommendations for reporting "black carbon" measurements, Atmos. Chem. Phys., 13, 8365-8379, doi:10.5194/acp-13-83652013, 2013.

Pope, C. A. and Dockery, D. W.: Health Effects of Fine Particulate Air Pollution: Lines that Connect, J. Air Waste Manage., 56, 709-742, 2006.

Pope, I. C., Burnett, R. T., and Thun, M. J.: Lung cancer, cardiopulmonary mortality, and long-term exposure to fine particulate air pollution, J. Amer. Med. Assoc., 287, 1132-1141, 2002.

Ramanathan, V., Li, F., Ramana, M. V., Praveen, P. S., Kim, D., Corrigan, C. E., Nguyen, H., Stone, E. A., Schauer, J. J., Carmichael, G. R., Adhikary, B., and Yoon, S. C.: Atmospheric brown clouds: Hemispherical and regional variations in long-range transport, absorption, and radiative forcing, J. Geophys. Res.-Atmos., 112, D22S21, doi:10.1029/2006JD008124, 2007.

Romanou, A., Liepert, B., Schmidt, G. A., Rossow, W. B., Ruedy, R. A., and Zhang, Y.: 20th century changes in surface solar irradiance in simulations and observations, Geophys. Res. Lett., 34, L05713, doi:10.1029/2006GL028356, 2007.

Rumsey, I. C., Cowen, K. A., Walker, J. T., Kelly, T. J., Hanft, E. A., Mishoe, K., Rogers, C., Proost, R., Beachley, G. M., Lear, G., Frelink, T., and Otjes, R. P.: An assessment of the performance of the Monitor for AeRosols and GAses in ambient air (MARGA): a semi-continuous method for soluble compounds, Atmos. Chem. Phys., 14, 5639-5658, doi:10.5194/acp-14-5639-2014, 2014.

Russchenberg, H., Bosveld, F., Swart, D., ten Brink, H., de Leeuw, G., Uijlenhoet, R., Arbesser-Rastburg, B., van der Marel, H., Ligthart, L., Boers, R., and Apituley, A.: Ground-based atmospheric remote sensing in the Netherlands: European outlook, IEICE Transactions on Communications, E88B, 2252-2258, 2005.

Schaap, M., Otjes, R. P., and Weijers, E. P.: Illustrating the benefit of using hourly monitoring data on secondary inorganic aerosol and its precursors for model evaluation, Atmos. Chem. Phys., 11, 11041-11053, doi:10.5194/acp-11-11041-2011, 2011.

Schlag, P., Kiendler-Scharr, A., Canonaco, F., Croteau, P., and Holzinger, R.: Q-ACSM PM1 chemical composition data at Cabauw, Wieselkade (station NL0644R) from 11 July 2012 to 3 June 2013, availalbe at: http://ebas.nilu.no, last access: 26 February 2015

Schmale, J., Schneider, J., Nemitz, E., Tang, Y. S., Dragosits, U., Blackall, T. D., Trathan, P. N., Phillips, G. J., Sutton, M., and Braban, C. F.: Sub-Antarctic marine aerosol: dominant contributions from biogenic sources, Atmos. Chem. Phys., 13, 86698694, doi:10.5194/acp-13-8669-2013, 2013.

Schwarz, J. P., Gao, R. S., Fahey, D. W., Thomson, D. S., Watts, L. A., Wilson, J. C., Reeves, J. M., Darbeheshti, M., Baumgardner, D. G., Kok, G. L., Chung, S. H., Schulz, M., Hendricks, J., Lauer, A., Kärcher, B., Slowik, J. G., Rosenlof, K. H., Thompson, T. L., Langford, A. O., Loewenstein, M., and Aikin, K. C.: Single-particle measurements of midlatitude black carbon and light-scattering aerosols from the boundary layer to the lower stratosphere, J. Geophys. Res.-Atmos., 111, D16207, doi:10.1029/2006JD007076, 2006. 
Seinfeld, J. H. and Pandis, S. N.: Atmospheric chemistry and physics: From air pollution to climate change, WileyInterscience, Hoboken, NJ, USA, 2006.

Setyan, A., Zhang, Q., Merkel, M., Knighton, W. B., Sun, Y., Song, C., Shilling, J. E., Onasch, T. B., Herndon, S. C., Worsnop, D. R., Fast, J. D., Zaveri, R. A., Berg, L. K., Wiedensohler, A., Flowers, B. A., Dubey, M. K., and Subramanian, R.: Characterization of submicron particles influenced by mixed biogenic and anthropogenic emissions using high-resolution aerosol mass spectrometry: results from CARES, Atmos. Chem. Phys., 12, 8131-8156, doi:10.5194/acp-12-8131-2012, 2012.

Simoneit, B. R. T. and Elias, V. O.: Detecting organic tracers from biomass burning in the atmosphere, Mar. Pollut. Bull., 42, 805810,2001

Simoneit, B. R. T., Schauer, J. J., Nolte, C. G., Oros, D. R., Elias, V. O., Fraser, M. P., Rogge, W. F., and Cass, G. R.: Levoglucosan, a tracer for cellulose in biomass burning and atmospheric particles, Atmos. Environ., 33, 173-182, 1999.

Sun, Y., Wang, Z., Dong, H., Yang, T., Li, J., Pan, X., Chen, P., and Jayne, J. T.: Characterization of summer organic and inorganic aerosols in Beijing, China with an Aerosol Chemical Speciation Monitor, Atmos. Environ., 51, 250-259, 2012.

Sun, Y.-L., Zhang, Q., Schwab, J. J., Demerjian, K. L., Chen, W.N., Bae, M.-S., Hung, H.-M., Hogrefe, O., Frank, B., Rattigan, O. V., and Lin, Y.-C.: Characterization of the sources and processes of organic and inorganic aerosols in New York city with a high-resolution time-of-flight aerosol mass apectrometer, Atmos. Chem. Phys., 11, 1581-1602, doi:10.5194/acp-11-15812011, 2011.

Trebs, I., Meixner, F. X., Slanina, J., Otjes, R., Jongejan, P., and Andreae, M. O.: Real-time measurements of ammonia, acidic trace gases and water-soluble inorganic aerosol species at a rural site in the Amazon Basin, Atmos. Chem. Phys., 4, 967-987, doi:10.5194/acp-4-967-2004, 2004.
Ulbrich, I. M., Canagaratna, M. R., Zhang, Q., Worsnop, D. R., and Jimenez, J. L.: Interpretation of organic components from Positive Matrix Factorization of aerosol mass spectrometric data, Atmos. Chem. Phys., 9, 2891-2918, doi:10.5194/acp-9-2891-2009, 2009.

Ulden, A. P. and Wieringa, J.: Atmospheric boundary layer research at Cabauw, Bound.-Lay. Meteorol., 78, 39-69, 1996.

Varga, B., Kiss, G., Ganszky, I., Gelencsar, A., and Krivacsy, $\mathrm{Z}$. Isolation of water-soluble organic matter from atmospheric aerosol, Talanta, 55, 561-572, 2001.

Vermeulen, A. T., Hensen, A., Popa, M. E., van den Bulk, W. C. M., and Jongejan, P. A. C.: Greenhouse gas observations from Cabauw Tall Tower (1992-2010), Atmos. Meas. Tech., 4, 617644, doi:10.5194/amt-4-617-2011, 2011.

WHO: WHO Air quality guidelines for particulate matter, ozone, nitrogen dioxide and sulfur dioxide. World Health Organization, 20 Avenue Appia, 1211 Geneva 27, Switzerland, 2006.

Xu, L., Guo, H., Boyd, C. M., Klein, M., Bougiatioti, A., Cerully, K. M., Hite, J. R., Isaacman-VanWertz, G., Kreisberg, N. M., Knote, C., Olson, K., Koss, A., Goldstein, A. H., Hering, S. V., de Gouw, J., Baumann, K., Lee, S.-H., Nenes, A., Weber, R. J., and Ng, N. L.: Effects of anthropogenic emissions on aerosol formation from isoprene and monoterpenes in the southeastern United States, P. Natl. Acad. Sci., 112, 37-42, 2015.

Zhang, Q., Jimenez, J. L., Canagaratna, M. R., Ulbrich, I. M., Ng, N. L., Worsnop, D. R., and Sun, Y.: Understanding atmospheric organic aerosols via factor analysis of aerosol mass spectrometry: A review, Anal. Bioanal. Chem., 401, 3045-3067, 2011.

Zhang, Y. and Wu, S.-Y.: Fine scale modeling of agricultural air quality over the southeastern United States using two air quality models. Part II. Sensitivity studies and policy implications, Aerosol Air Qual. Res., 13, 1475-1491, 2013. 